\title{
Af Prasteindberetninger fra Ribe Stift i 18. Aarh.
}

Ved H. Weite meyer.

(Fortsættelse fra Aarg. 1910).

Tørninglens Provsti.

I. Hvidding Sogn.

Hvidding Sogn. Der er to Indberetninger af J. Ewald, dat. 30. Decbr. 1765 og 15. Jan. 1768.

Af Præstelisten: Fredr. Chr. Hammer blev fundet død i Fiskeparken 18. Febr. (ikke Juni, som Wiberg har) 1764. - Om sig selv siger Jochum Enald ikke et Ord.

Vedlagt er en Kopi af et paa Latin affattet Salvegardebrev for Thomas Henrichsen Weile, Præst her fra 1647 til 1672 (d. 1686), hans Familie og al hans Ej.endom i Hvidding, dat. 2. Novbr. 1659 og underskrevet af dansk Krigskommissær ved den polske Hær, Nicolaus Nissen.

K i r k e n*) er overalt belagt med Bly. Den har et malet Loft, lagt i Rammer, undtagen Sakristiet er Vælving (!). S. ø. for Kirken staar Klokketaarnet af Bindingsværk, belagt med Bly. Paa den store Klokke staar: Hans van Damme gut mi tho Hamburg MDLXXXIX. Den X July disse Klocke De Het Geten

*) Om Kirken se Trap, Slesvig p, 84, og Haupt, II p. 426. 
laten der Er und Fester Juncker Lodwich Nielsen Arf Gesessen tho Hyxbru, Trulus Nielsen tho Asstorp. Paa den mindre staar: Claus Asmussen me fecit 1696. En gammel katolsk Altertavle, hvorpaa findes Paternosterbaand, i hvis Midte Christus hænger paa Korset med en Del Helgener omkring sig. Udi Sakristiet findes en gammel Antikvitet med Jerngitterværk for. Paa Væggen et Skab, hrorudi staar et Fruentimmer med et Barn paa hver Arm og to andre Billeder ved Siden. - Paa Prædikestolen staar: Ahno Dmi 1599 den 5. Febr. - Paa norre Væg findes to Epitafier af Træ, det ene over Præsten Thomas Henriksen Weile og to af hans Born, Henrik, d. i sit 12. Aar, og Christen, d. i sit 15. Aar, det andet over Hans Wedel og Hustru og Clemend Jorgensen Fog og Hustru Magdalene Wedel, f. 1691. Der er to murede Begravelser i Kirken; den ene tilhorer Hoxbrogaard, hvorudi, som der siges, nogle af de gamle Rantzouer har været begravede, men for nærv. Tid er ingen uden de to sidste Beboeres Jacob Bjorns og Anders Andersens og deres Familiers Ligkister at finde, hrorpaa ingen Inskription. Den anden Begravelse tilhorer Præstegaarden, bekostet af Thomas Weile for 29. Rd. 2 Mk. 4 Sk. (Epitafiet kostede $32 \mathrm{Kd} .3 \mathrm{Mk}$. foruden Træet), og der staar mine. Formends og deres Familiers Kister, hroriblandt to med Inskr. over Clemend Fog (efter Indskr. er han fodt 3. Febr. 1682 og blev gift 1707) og Fredr. Chr. Hammer. Paa den sidstes Kiste staar flg. Vers, der minder om hans Dodsmaade (blev funden dod i en Park ved Præstegaarden, ventelig af en Svimmel nedfalden): 
I Vandet gled min svage Fod

Og faldt i Døden hen,

I Jesu Sides Vand og Blod

Jeg rejses op igen.

Neden i Kirken et smukt malet Pulpitur til Mandfolk, og paa det staar med malede og forgyldte Bogstaver (paa Latin), at Johannes Thomas Wellejus 1704 lod det bygge paa egen Bekostning, og oren- og nedenunder staar:

Det Pulpitur Hr. Wedel har

Til Kirken villet give,

Da her paa Stole Mangel var,

Det Gud til Fre blive,

Men trærtimod til denne Tid

Ilar voldet Strid og Klammer

Og Kirken garnet ej en Hvid,

Det er jo Synd og Jammer.

Clemend Fog 1744.*)

Kalk og Disk af Solv forgyldt er af Kirken selv bekostet. I Alterklædets Midte staar 1661.

Vides ikke, at Kirken har haft nogen Fata af IIdebrand eller anden Forandring; den er ej heller nogensinde bleven større, end den er. I sidste Sommer (1767) blev den efter kgl. Befaling takseret ved Branddirektaren iHaderslev for 4000Rd.-Paa Kirkegaarden 8 Ligsten, hvoraf den ene er mærkværdig formedelst den derpaa udhugne latinske Indskrift: „Her-

*) I Indberetningen fra $176 \zeta^{4}$ staar flu., der vistnok giver Forklaring til Verset: Her var en liden Misfornajelse blandt Sognefolkene, da de i Anl. af, at Pulpituret blev bygt, matte forandre deres Stader i Kirken, hvilket ikke uden Allarm bortfaldt, 
under hviler Soren Nielsen af Hvidding. Nascimur in puncto, Patimur quam Plurima Mundo, Morimur in Puncto. Quid sumus? Ergo nihil. Haud timet Mortem Qui Vitam sperat*). Herunder hviler sl. Karen Tyges D. af Hriding 1687.

Kirken har intet Hrtk., men dens Indkomster er den (30. Kærv af alle Slags Korn, som in natura aarljg leveres til Kirkevargerne . . . Desuden ligger til Kirken et Stk. Eng, kaldet Kirkens Toft, hvoraf betales aarlig 4 Mk. $8 \mathrm{Sk}$. - Dens staaende Udgifter er: til Biskoppen 6 Mk., Caathedraticum 2 Mk., Herredsprovsten $3 \mathrm{Mk}$, Studenterpenge til Haderslev Skole 3 Mk., Amanuensis \& Sk., til Brod og Vin samt Klæder at to $18 \mathrm{Mk}$. $12 \mathrm{sk}$. (deraf de $12 \mathrm{sk}$. til det sidste), Degne- og Skolemesterpenge $6 \mathrm{Mk}$., de Fattige $1 \mathrm{Mk}$. 8 Sk., endnu betaler Kirkerærgerne, som tager mod Kirkens Tiende in natura, aarlig Haderslev Skole for Straaen 8 Mk., Fortzering ved Kirkens Regnskab 5 Mk. - Summa J3 Mk. 12 Sk. Nok [endnu] betales Degnen for Ringen aarlig 10 Skpr. Rug og 5 Skpr. Byg.

Ko n g e ti e n d e n er lige som Kirkens den 60. Kærv af alle Slags Korn, hvilket hvert 3. Aar kommer til offtl. Licitation paa Haderslev Amtstue og koster fra 20 til 30 Rd., som Sognet selv i mange Aar har nydt.

Præstegaarden staar for " "Plov; dens Bygning bestaar af 98 (?) Fag dels Grundmur, dels

*) Vi fodes i et (Yjeblik, vi lider det mest mulige i Verden, vi dur i et (Yjeblik. Hvad er vi? Altsaa intet. Den frygter ikke Døden, som haber paa Livet, 
Tavlmur og dels Trærægge kun i slet Byggestand og kostede ved sidste Indkob 883 Rd. . Den har god Ager og Eng, der undertiden lider Skade ved at overskylles af Havet; der kan indavles aarlig henved $200 \mathrm{Tdr}$. Byg, 36 til 40 Tdr. Rug, 16 til 20 Tdr. Havre, 10 til 16 Tdr. Bønner og 1 à 2 Tdr. Erter, og af Engene kan indavles 40 til 60 Læs, græsses og fodres 32 til $36 \mathrm{Hø-}$ veder. - Om Tørvjorden har Thomas Wedel haft Proces med Lundsmarks Beboere, som paastod, at Jorden tilhørte dem og var overladt Præsten af Godvillighed, men Præsten paastod, at det var Præste. gaardens Ejendom; da han tabte Sagen ved Hjemtinget, vilde han appellere til Overretten, og Beboerne gik derfor af Frygt for Bekostningerne ind paa, at Præsten skulde beholde Jorden, mod at de ikke skulde give ham som før Kræatiende og Offer; Clemend F'og havde ogsaa Udstand med dem om samme Sag og fik skriftlig Akkord med dem paa samme Betingelser for sig og Arvinger, saa længe nogen af dem var ved Kaldet. Med mig begyndte de ligeledes, og jeg maatte indgaa paa samme Akkord, ja endog give dem den halve Smørtiende, men derom er dog intet skriftligt. - Til Enkepension svares aarligt af Kaldet 3 Tdr. 6 Skpr. Rug, og 5 Tdr. Byg (Tønden 10 Skpr.), en Ottendedel Smør og i Penge 12 Rd. 20 Sk.

Sognet bestaar af adskillige Slags Tjenere: 1) kgl. Undersaatter, som sorterer under Haderslev Hus og bestaar af $1411 / 18$ Plov, 2) Cuxbølske eller Rantzowske, som er ${ }^{37 /}{ }_{72}$ Plov, 3) Schackenborgske, hvis Hrtk. er 22 Tdr. 1 Skp., 4) Lectorats Gods, som sorterer under Ribehus og bestaar af $20 \mathrm{Td}$. 5 Skpr. Hrtk. 
I Hviding By, som i gamle Dage kaldtes Hvilling og vel har sin Oprindelse af den Fisk Hvilling, befindes $73 / 4$ hele Gaarde og derpaa 19 Beboere, derforuden Forbedelser og Inderster 8 Steder; ved Raahede befindes 9 hele Gde. og derpaa 16 Beboere, derforuden Forbedelser og Inderster 10 Steder; i Endrup er 2 $1 / 2$ Gd. og derpaa 5 Beb.; i Lundsmark er 3 hele Gde. og derpaa 3 Beb.; i Hoxbro er 6 hele Gde. og derpaa 9 Beb., derforuden Forbedelser og Inderster 8 Steder.

Sognets F a tige er for Tiden (1765) 5; til deres Forflegning er ordineret en Sparbøsse i hver By, hvorudi samles alt, hrad ved Trolovelser og Bryllupper samt Kob og Salg enhver godvillig vil give, dernæst Tavlepengene, den øvrige Rest bliver lignet over samtlige Beboere. De 5 nyder tils. 75 Mk. 6 Sk. Jens Henningsen Fog i Raahede har ved sin Død legeret til Sognets Fattige $100 \mathrm{Rd}$, , hvis Renter uddeles hver Nytaar og St. Hansdag.

Et Sk o le h u $\mathbf{s}$ Ø. for Kirken er opbygget og til et bestandigt Skolehus indrettet 1697. Skoleholderens Lon er af ethvert Barn ugtl. 1 Sk., og af Kirken nyder han aarlig for de fattige Børn 24 Sk., videre visse tillagt har han ikke. Skoleholderen er pligtig at holde Skole baade Vinter og Sommer, men holder alene om Vinteren, fordi det om Sommeren mangler ham paa Børn. Substituten har altid haft Skolen, som af Biskoppen i Ribe bliver beskikket . . .

Der siges at have været en adelig Gaard, som nu kaldes Hoxbrogaard, som endnu har adskillige Friheder; den giver ingen Kirketiende, til Præsten gives 
der ingen Kvæg- eller Smørtiende, af Korn gives der aarlig 1 Ørt Rug og 1 Ørt Byg, som er ikke den halve Part af det, der kunde gives; den giver 32 Sk. til Offer, enten Familien er stor eller liden. - I Raahede er en Gade kaldet Klostergade, fordi der i katolske Tider har ræret et Kloster.

Personernes Antal over 12 Aar er (1765) 393; de Dode er ungefehr aarlig 20 til 24, de Fødte 24 til 27.

Sognets bedste $\mathrm{N} æ \mathrm{r}$ ing er Avling og Opdræt. Der avles fornemmelig Rug, Byg, Havre, Bønner og .irter, hroraf mest afsættes Byg, som gøres i Malt . . . Fiskeriet har i fordums Tid været i Overflødighed af de saakaldte Flynder (eller Plader) og Butter (Rødspætter), saa at Beboerne ej alene kunde have noget til egen Fornødenhed, men endog sælge deraf til andre, hvilket for nogle Aar siden saaledes har forandret sig, at der nu moxen intet bekommes. - Raahede, Endrup, Lundsmark og Høxbro deres Rugland kan bruges i 3 Aar og hviler i 4. Aar; derforuden har Raahede, Endrup og Høxbro noget Bygland, som hvert Aar bruges og kaldes Alt-Sæd-Jord. Hviding By har intet uden Alt-Sæd-Jord, som hvert Aar bruges og gødes uden at hvile. - Raahede og Høxbro har deres fornodne Brændsel og Lundsmark til Overflødighed, alle af de saakaldte Flad-Torv, Endrup nogen liden, men ikke til Fornødenhed, og Hviding har selv ingen Brændsel.

Af vilde Dyr ses undertiden Ulve.

Roager Sogn. Indberetningen af Chr. Schmidt (d. 1767), er udateret. 
Af Præstelisten: Om Præsterne før Reformationen har jeg ingen Kundskab uden det, der læses hos Helvaderum*), om Hr. Peder Roager, som valgte sig selv til Biskop [1465], hvilket stedse her i Sognet har været en troværdig Tradition, som enhver ved at tale om. Om Præsterne efter Reformationen har jeg ej andet end en liden Opskrift bag paa Altertavlen, som er hel utilstrækkelig, og dernæst en Fortegnelse paa Præsterne udi Hviding Herred fra Reformationen af, som og er utilstrækkelig, hvilken hermed følger til Eftersyn (den er vedlagt). .Ved samme Fortegnelse kan endnu efter Kirkebogen erindres: . . . . Niels Astrup (d. 1701) var født paa Astrupgaard i Brøns Sogn og, som minFormand har skrevet i Kirkebogen, af en ældgammel Familie, hvis Slægtsregister fra 1508 skal forefindes, men er mig ubekendt. Nissenius Hygom var fodt 1672 i Hygom Præstegaard . . Af hans Børn opholder sig endnu 3 Dotre i Ribe. I hans Tid 1714 19. Aug. blev Præstegaardens Ladehuse med alt indavlet Hø og Korn afbrændt formedelst Tordenild. Christian Schmidt. . . var 9 Aar Collega i Viborg Skole . . ærgtede 1741 Maren, Datter af Køb- og Handelsmand Jørgen Schaltz i Viborg; 1746 kom han i 2. Egteskab med Dorothea Marie Outzen.

Hvoraf K i r k e n har Navn, kan jeg med Vished ej sige, men jeg har hørt, at Sognets Mark fra gammel Tid har været begroet med Skov og Buskads, som Tid efter anden er opryddet og gjort til Agerland og har derfor faaet sit Navn af at rydde Agre, saa at det skal være kaldet i Begyndelsen Rydtager. Den har et lidet

*) Det er Niels Helvad, „Eleusinia sacra“ osv. (1610). 
Spir paa Taarnet og Afsættelser (?) paa den lave Kirke foruden en Runddel med Hvælving over Koret og Alteret, overalt trekket med Bly, har og et Vaabenhus, en Sakristi, et Pulpitur, nye Stole med Døre, og smukt malet indvendig overalt. Bygningen er velproportioneret og har en smuk Skikkelse inden- og udvendig. En Klokke i Taarnet og to smaa ubrugelige Klokker staur i Kirken. Kalk og Disk er af Sølv forgyldt, og en do. Kalk og Disk til Syge at betjene. Paa Alteret 4 Messing-Lysestager. Indskriptioner findes ej uden ordinære paa Bondernes Ligstene undtagen para en liden Ligsten i Kirken over Hr. Hans Clausen, hvilken er mærkværdig af $\sin$ Enfoldighed. Stenen er ej storre end som den kunde ligge over et lidet Barn par 3 a 4 Aar; dens lndrettelse er i alle Maader saaledes, som efterfolger. - Her folger en Tegning af Stenen, der er uden Prydelse. Paa Midten staar: Her Hans Clawsen. Gud werre hans Seel naadig Amen. H. C.; Omskriften er: Anno 1590 den 8. Miarts dode sl. med (iud Her Hans Cilawsen, Guds Ords Tjener til Roager Kirke* ${ }^{*}$.

Her i Egnen er Bundergaardene ej anslagne for Hartkorn undtagen nogle faa Riberhus-Bonder som Strugods her i Sognet, og Kirkerne her nyder kun hals Tiende med Kirkerne i Danmark. Kirkens aparte Ejendomme bestaar i nogle Agre og Enge, men hrormeget det er, haves ej nogen Efterretning om, og Kir-

$\Rightarrow$ Det er Presten Johan Clausen Normsted. Abiligaard, som hesogte Kirken 1776 (se sonderj. Aarl. 16Hk6, p. 13భ', omtaler ikks Limstenen; den var maaske allerede da forsvundet. Om Kirken se Haunt, I. 1. 414. 
ken nyder aarlig deraf $4 \mathrm{Mk}$. Hr. Niels Astrup har haft stor Disput og Proces om disse Kirkens Jorder, endog efter at han havde erholdt kgl. Koncession til Jorderne at bruge for samme Afgift, som Bønderne havde det, men hvad Ret og Adgang enten Bønderne havde til at besidde Jorden for saa liden en Afgift eller Ilr. Astrup til at erhverve sig den Fordel fra Bønderne, kan jeg ikke sige med nogen Vished. Imidlertid gik Jorderne til Præstegaarden og har lagt dertil i 60 Aar, indtil jeg som en fremmed kom til Landet, og da bemægtigede Bønderne sig Jorderne uden at spørge mig derom, og at de kunde være desto tryggere, søgte de Fæstebrer paa Jorderne ved Amtshuset i Haderslev. Jeg ser ikke, at Præsten kunde have nogen Ret til Jorderne, men det ser jeg, at Kirken faar ej nær den Afgift, som kunde faas af dem, og tillige, at det var Uret, at Amtshuset tilegnede sig Ret til at fæste og til at beholde Fæstet, da det ikke har haft eller endnu har noget mèd Kirken at gøre.

Kongen har altid ejet Kirken og har altid kaldet; dog menes der, at det har været Valkalde (!) her af fordums Tid, som endnu er i Fyrstendømmet paa de fleste Steder brugeligt, hvilket man slutter af adskillige Ting ....

K ongetienden bliver hvert 3. Aar bortforpagtet paa Amtshuset i Haderslev, men det har en særdeles Beskaffenhed her som for andre Steder, thi en stor Del er fritagen for at give Kongetiende.

Præste ga arden, som er Haderslevsk Grund, staar ej for Hrtk., men maa regnes for ongefehr \% Plow; ellers er her i Byen en hel Gaard, Riber- 
husgaard, af lige Beskaffenhed med Præstegaarden, og den er noget over 9 Tdr. Hrtk.

Kirkeby siges af førdums Tid at være kaldet Sonder-Roager. . . Desuden et lidet Skovhus kaldet Stavetskov formedelst en lille Skov, som ligger derved, tilhører det Castellisk-Rantzowske Herskab.

Naar her er nogen F a t t i g, som ej kan ernære sig, har de maanedlig af Sognet saa meget, som fornødent eragtes, og den Fordeling gøres af Præsten, Sognefogden og nogle Mænd, hvorefter Helligbrødre. fogderne skal indkræve Pengene. Desuden bliver Kirkens Tavlepenge henlagte til de Fattige, men naar ingen Fattige er, bliver de Kirken beregnede. Her er og et lidet Legatium paa $22 \mathrm{Rd}$.

Herregaarde findes ikke, men Westerbcek By, som er adeligt Gods, tilhørende det Castellisk-Rantzowske Herskab, har af ældgammel Tid været beboet af en Adelsmand, men hvad hans Navn har været, er mig ubekendt. Siden er WT. beboet af Bønder, som endnu beholder den adelige Frihed, at de svarer ingen Tiende til Præsten og ganske lidet til Kirken. Min sl. Formand har, men forgæves, gjort sig svær Umag for at faa de præstelige Indkomster af Westerbæk . . .

$\mathrm{N} æ \mathrm{r}$ in g e n bestaar i Agerdyrkning og Opdræt af Kreaturer. Rugavlen er ganske liden, saa en Del af Bonderne maa undertiden købe Rug til deres Husholdning, derimod avles godt Byg, som Bønderne gør til Malt og sælger det til Ribe, Løgumkloster og omliggende Kroer; af Havre kan ogsaa sælges noget, Boghvede avles knap til Fornødenhed og af Erter ej mere, end hver i sin Husholdning kan behøve. En god 
Fordel har Bønderne af det bekvemme Ler til Teglbrænderi, som de for nogle faa Aar siden har fundet, og deraf faar ej alene en god Hjælp til deres Husholdninger, men endog har kunnet sælge deraf til andre.

Spandet Sogn. Indberetningen, af Andreas Jacobsen Boysen, er dat. 26. Marts 1768.

Til Præstelisten findes næsten intet undtagen Series Pastorum, som er ophængt i Kirken af Boysen selv (se ndfr.) Ellers bemærker han bl. a.: Min Formand sl. Hr. Rasmus [ 0 : Rasmus Hansen Kiersing, Præst 1689-1723] ægtede Enken paa Stedet, som var en Præstedatter fra Hygum. Sl. Hr. Kruse [Præst her 1730-49] bekom hans Hustru fra Kobenhavn og hedde Haugen. Min Moder, som er i disse Dage død hos mig, var 97 Aar og kunde tælle Burn, Bornebørns Børn med sig selv iregnet i 5 Led.

K i r k e n, saavidt jeg ved, St. Jacobs Kirke, er meget kont bygget efter udvortes Proportion med en Rundeel ved Østerenden, af huggen Sten; især er der en Del forunderlige Mursten, som ej er brændte, men synes, ligesom de var af graa og ubrændt Ler, som er poruse, men af saadan Durabilitet, at de ventelig har siddet i Kirken nogle Secula; de er udi alle Maader som en Pimpsten, men er dog ej Pimptsen. ${ }^{*}$ ) Den er tækket med Bly overalt undtagen faa Fag Norden paa Kirken, som er klædte med Brædder og overstrogne med Blyfarve; Taarnet, med Spir, er og-

*) Det er Tufston, Prasten saaledes heskriver. Um Kirken se J. Helms, Tufstenskirkerie i ('megnen af Ribe, p. 28 og 42 flg., Trap, Slesvig 1. 87 , og Haupt, I. p. 421. 
sa dig, at naar man er nær Kirken, man næppe kan hare den; den er saa sprokken og revnet, saa den med Fare maa bruges, at nogle Stykker sidder lose i den. Cister- og Vesterdelen af Kirken er med Velvinger, men mellem Koret og Taarnet er der Left. - Alterets Arbejde er med de 12 Apostle prydet, ellers er det kuns malet med bibelske Historier, som Nadverens Indstiftelse, Opstandelsen og Himmelfarten. Kalk og Disk er af Sølv forgyldt. Paa Prædikestolen staar: Chr. 4. 1640; nedenunder: F. W. Christian Rantzou til Bredenbeck foræret til denne Prædikestol 10 Rd. I Kirken er to Tavler, for nogle Aar opsatte; paa den eise staar, at en Kniplingspige i Sognet har givet et Legat til Kirken paa 100) Rd.*) og desuden, hrad enhver har givet gratis til Kirkens Reparation; den anden Tavle er opsat (og bekostet) af mig 1754, hvorpaa er tegnet Series pastorum. I Kirken er to Ligsten, paa Kirkegaarden 10. Der har været adskillige Disputer om Kirkestole, nogle har saare mange, nogle har altfor faa, der er stor Uenighed. Degnens Hustru har ingen, Præstens Tjenestefolk er forflyt at staa snart hist snart der hos en Væg.

Der er en og anden Bonde i Sognet, som har Kirkeagre, hroraf gives noget lidet. - Det er Kongens Kirke, der er vurderet for 150) Rd.

Der er kun 5 Mand i Sognet, som giver $\mathrm{K}$ o n g et i e nde, der erlægges under Haderslev; de øvrige

*) Se D. Atlas V. p. HTt, som siger, at Altertavlen er givet 17ti af en Kniplepige Anne Nislsilatter. 
giver ingen, som sorterer under Gaardene Castel og Schackenborg.

I mine Formænds Tid var den bedste halve Gaard i Spandet til Præstega arden, men da sl. Hr. Knudsen*) kom, vilde han ikke give Arvingerne noget derfor, hvorover Rettens Betjente lod den sætte til Auktion, og er nu en Fæster boende. - Af Kaldet svares 24 Rd. i Enkepension, dog gives af Barmhjertighed mere end de jure.

I Spandet er 12 [Beboere?] foruden Præsten; den bestaar af 17 Ottinger. Fjersted bestaar af 17 Ottinger, Spandetgaard af $8 \mathrm{Ott}$, hvorhen hører Spandet Kro. Molbye bestaar af en hel Gaard, som er delt i 13 Toft-Værelser, og ligger hvert Hus temmelig vidt fra hverandre. I Spandet er der egentlig ingen enlige Steder uden Spandet Kro. Om Fjersted vides, at det $\mathrm{i}$ Gabels Dage har bestaaet af 4 separate Steder, som nu er samlede i eet.

Sognets bedste $\mathrm{N}$ æ r in g er Ager og Eng; der er god Agerland, England er næppe til Fornødenhed. Der saas Rug, Byg Havre, Boghvede, Bønner og Frter, hvoraf Rug og Byg mest saas, Havre og Boget kun til egen Fornodenhed, Erter og Bønner kun ganske lidet af en og anden. Der kan sælges Byg og Rug af nogle, men ej af det andet. Jorden hviler i 3 Aar. Avlingen kunde forbedres, naar den efter kgl. Kon-

*) Det er Frederik Knudsen, der var Kapellan her, idet Spandet hørte til IIøjrup indtil Knudsens Død 1630, men styredes af Kapellaner. Det er om ham, der fortalles, at Sognefolkene bar ham til Kirken, da han havde faaet Paalag om ikke at gaa fra Kroen derhen. „Det gaar an, sagde Spandet Præst, da de bar bam fra Kroen til Kirken." 
cession blev separeret. De kan sælge en hel Hob Tørv og Klyner. Til Fjersted By er der en liden køn Skov, dog er der megen Krat imellem, de har og Mosetørv i Overflødighed, men kun lidet Klyne-Jord. Til Spandet By er der alene Busk og Krat, men ej nogle Træer, de har Mose- og Klynejord i Overflødighed. Til Spandetgaard og Mølbye er ingen Krat, men de har Tørve- og Klyne-Jord nok. Af Klyne og Tørv sælges en Del til Ribe. - En Dam kaldes Snerp Dam, der tilhører det Castelliske Herskab, i hvilken findes Gjedder og Aborrer, men formedelst dens Dybde er de ikke godt at faa deraf. - Der er en Del Kniplingspige-Vævere.

Der er af vilde D y r Harer, Ræve, og sommetider Raadyr og L'lve...

B y g n inge rne er alle i god Stand efter Bonderskik med Brandmur opførte, ja i de fleste Huse, hroraf nogle har staaet over et Seculum efter de der antegnede Aarstal, er Tømmeret, Bjælker og Sparrer af det kosteligste Eg, derimod i den liden Molby er Husene saare ringe. Dette Egetommer skal i forrige Tider have rokset paa Spandet Mark.

Om den ene By næst Kirken er kosteligt Ler, hvoraf brændes saare solide Mursten, som er endogsaa under Vandet i Brøndene næsten uforgængelige. Leret er af den Beskaffenhed: ongefehr 3 a 4 Alen er Leret gult, men graver man dybere, hvor de ingen Bund endnu har kunnet faa, er det dunkeltblaat, og Erfarenhed har vist, at de Sten, der bestaar af det blaa Ler, naar de andre af det gule Ler faar deres fornodne Maturitet af Ornen, saa lober de blaa sammen $i$ en glasseret Klump, som ved ingen Kunst eller 
Gewalt kan separeres mere. Her er en Slags StøbeSand paa vores Mark i temmelig Kvantitet, hvoraf de Kyndige af alle Købstæder omkring ved os, især dem, som omgaas med Stoben, hente med stor Onhyggelighed. Der er vel paa Spandet Gade en stor Del gult Ler, men er ej tjenligt til at brænde Sten af, thi den er fuld af hvid Kride og andre smaa Sten, men at mure med er det overmaade godt, naar Sten og Kride bliver afsamlet.

Antal Personer er ongefehr 200, de dødes og fødtes Antal aarlig 8 à 10 af begge Slags, sommetids mindre.

Paa Markerne er mange Høje og deriblandt de saakaldte hedniske $\mathbf{L} \mathrm{u} \mathbf{n} \mathrm{d}$ e, hvori findes overmaade store Stene, som er rangeret, derimellem var ordentlige Kældere, og er nu af Bonderne bleven kløvet og ruineret. Bønderne har foræret mig en Offersten, ogsaa to Instrumenter af en rar Slags Metal, ventelig af det saakaldte Es Corinthiacum, som ser ud som en liden Dolk og er skarp til begge Sider, den spidse Ende er afbrudt; Hæftet, som er ej længere end to Tolde, er hult, at det kunde sættes paa det Instrument af samme Materiale; jeg kan ikke just determinere Figuren.

Der er ongefehr $3 \mathrm{Fat}$ ig e, som gaar omkring og nyder deres Føde. - Der er vel et $\mathrm{Sk}$ olehus bygget N. Ø. for Kirkegaarden af nogle af Sognemændene for en 15 Aar siden, hvori Degnen bor og giver Husleje af. Men der er desuden i hver lille By et Paı Fag Skolehus opbygget, hvori der holdes Skole ikkun om Vinteren. Der har været store Disputer om den 
Sag saavel som om andet; der er ellers ingen visse Skoleholder uden Degnen, men de andre er ustadige.

Nærværende er ingen Herregaard, men da den grevl. Rantzou-Castelliske Herskab nyder største Del af Sognet, er de ogsaa Ejere af den saakaldte gamle Herregaard Spandetgaard, som nu er udlagt til Bøn. dergaarde, og bestaar Bøndernes Antal derpaa af 4 halve Gaarde, som ligger ved Kirken. Herremand (?) paa denne Mark er ordentlig ved 4Skjelstene indhegnet og ligt et ene Mærke, og da der i Sognet 3 Herskaber, nemlig den kgl. Jæger, den højgrevl. Castel. Jæger og den højgrevl. Schackenborgske Jæger, har at jage. Men paa denne Mark har ingen Rettighed uden den Castelliske Jæger. Den sidste Herremand, der boede derpaa, ligger begravet i Ribe Domkirke og hed Claus Sehested, hans Epitafium staar straks ved Amtmandens Stol; hans Frue bekom han fra Caspargaard, og blev ham da et Donativ skænket af 2 Enge ved Ribe, nemlig Kokhal og Mol Enge, som disse Mænd i Spandetgaard endnu ejer, og har jeg selv nogle Aar nydt for Betaling en af disse Gaarde, som nu er afhændiget. Der ligger og paa denne Mark en Mose, som kaldes Hojmose, Norden for Kirken; den har for et Seculum været saare høj og ligesom et Refugium for Fjendens Anlob efter de gamle i Sognet deres Beretning; den var impassable at komme til uden paa et visse Sted, hvor de Gamle flyttede alle deres Mobilier og var selv som $i$ et sikkert Asylum i Fjendetid, men nu under Tidens Længde kan den med Rette kaldes Lav-Mose, thi den er mange Gange opgravet helt igennem, og altsaa har den tabt sin Højhed. Der er endnu i Bun- 
den den kostelige af Ribe Borgere elskede Høj-Mos Klyne, som graves i Førstning usigelig store, men naar de er blevne tørre, er de saare smaa og haarde og sorte; de er af en besynderlig salpetrisk Materie, saa at ingen Brygger kan bruge dem, thi de fortærer Kobberet, men til Varmen er de overmaade gode . . I Bunden af denne Mose ligger der store Runter*) af Gran eller Fyr, sommetids lange Stykker som Balkier (!), men de er alle brændte og Kuul (!) i Enden derpaa, saa at den Skov, som har staaet, hvo ved hvor mange Secula, der er afbrændt. De Fattige i Sognet opgraver disse Runter, og naar de er torre, kan de rive og splitte dem ad i smaa Ribber og bruge dem som Lys.

Den liden By, som ligger næst hos, er af den daværende Herremand bleven saaledes inddelt i saare smaa Boliger, som han har betjent sig af til at lobe Bud og andet Havearbejde. - Westerbcek, som ligger i Roager Sogn, og en Skov, Staved Skov, som endnu er i prægtig Stand, har hort samme Herremand til.

Højrup Sogn. Indberetningen er udateret og uden Narn, men er sikkert skrevet af Niels Müller, der var Præst her 1765-75.

Af Præsteliste $\mathrm{n}$ : Høyrup og Spandet havde een Præst indtil 1630, da Herremændene paa Spandetgaard sogte at faa dem selv en Præst. - Jens Togersen Ferslev (d. 1712) ... hans Hustru hed Maren Pedersdatter Hegelund. - Mads Pedersen Schjerning. (d. 1729) ... var Hører ved Kolding Skole i 18 Aar ...

*) En Runte er en Springstok (ifl. Kalkar). 
hans Hustru Apelone Kirstine Ferslev døde 1746, 57 Aar gl.; deres efterlevende 5 Børn: Peder Hegelund, Hospitalspræst i Kolding, Jens Schierning (se ndfr.), Maria Elisabeth, nu Kræmmerenke i Brede, Anna Else, Hr. Blangsteds Kæreste i Rødding, Sophie Elisabeth, Hr. Ewalds Enke i Schodburg. - Henning Nissen ... frekventerede Haderslev Skole fra 1703 til 1710, da han blev dimitteret til Kieler Universitet, hjemme hos sine Forældre til 1713, to Aar i Jena og Witenberg, siden Informator hos Ober-Auditeur Walthers i Kobenhavn i tre Aar, informerede Oberst Løvenshjelms*) Børn paa Weirup 1722 til 1728, assisterede derpaa sin syge Fader et Aarstid, kom til Høyrup 1729 . . . Jens Hegelund Schierning . . . fik Kaldet (1752) af sin Stiffader mod aarlig Pension, . . . efterlod sin Enke Voldborg, Hr. Johan Arendt Roses Datter i Gjording, med 5 smaa Børn.

K i rken s**) Alder og Narn kendes ikke. Den er tækket med Bly, bygt af Teglsten og Cement ( ikke over 40 Alen lang og næppe 10 Alen bred inden Muren og har et ikke ret højt, særdeles simpelt firkantet Spir. Den har kun een Klokke, hvorpaa staar: Borchardt Gelgiesser m. f. 1611. Verbum Domini manet in æeternam (Borchardt G. har gjort mig. Herrens Ord bliver $i$ al Evighed). Under Taarnet er Hvælving, ellers Loft. Paa Altertavlen staar noget gammelt Billedhuggerarbejde, der maaske skal forestille den yderste Dom, saa og de 12 Apostle og 4

*) Det er Hans Brockenhuus-Lowenhjelm til Vejrup i Fyn.

**ak) Om Kirken se Haupt I. Pg. 405. 
store Propheter eller Evangelister. Jeg sætter med Flid maaske, thi Mesteren har gjort det saare kludderagtigt, da han burde have sat til, hvad det skulde betegne. Nedenunder staar:

Til Klæedning min een 10 Rigsdaler har leveret, Gud glæde dem, som saa mig paldtet klædet har. Mad. Anna sl. Forvalter Carstensens.

Een to Gang $10 \mathrm{og}$ mer mig dertil har foræret, Gud dem velsigne med hvad Himlen selv formaar.

Hæderborne Apelone Kirstine Hr. Schiernings. Anno 1716.

Det er vel noget af den Donation, som Kirken har at takke for en smuk Fløjels-Messehagel. Kalken, af Sulv, holder 1; Bouteille. Paa hver af Messing-Lysestagerne staar: "Er foræret fra Anders Nissen Hørup 1635 til Hørup Kierck. Karen Anderskon«. Det er vel ikke værdt at anfore, at bag Alteret staar en liden, men gammel Trækasse, indlagt i Messing med Apostlenes Narne og couleurede Billeder paa; har der deri veret nogle Relikvier, saa kan det siges om den Helgen: Surrexit non est hic (det er ikke her, han er opstaaet). Ved den nørre Side af Alteret er for en halv Snes Aar siden sat en liden Udbygning, hvor otte Personer ad Gangen kan absolveres. Prædikestolen har ingen ornamenta, men alene den Inskription: Vivo ego, inquit dns., nolo mortem peccatoris, sed ut convertatur et vivat. Anno 1582 (Jeg lever, siger Herren, jeg vil ikke Synderens Død, men at han skal omvende sig og leve) ... Desuden har Kirken et Pulpitur, gjort 1729 og malet 1750 . . . I Kirken er kun to Ligstene over Præsterne Ferslev og Mads Schierning, 
hvorpaa nogle momenta vitæ staar, forresten uden Kunst og Kløgt. Paa Kirkegaarden er tre, hvorom heller ikke er noget at anføre, uden det skal være det latterlige, at paa en af dem, som i sin Tid er lagt over en Skovrider, staar, da Resten er dansk, et uheldigt latinsk Ord: Hans kære Hustru n a t u s etc. Efteríommerne kan tæenke, at Latinen ikke har været meget gængse; dog i den gamle Rom selv har der undertiden sprunget en grammatikalsk Maske for Skuespillerne, hvorpaa Bonnichay de antiq. Vrb. Rom fac. har et Par artige Exempler.

Kirkens Indkomster ved jeg intet andet om end, hvad der staar $\mathrm{i}$ de aarlige Kirkeregnskaber, uden denne underlige Skik skal anføres, at naar Klokken ringer for et Lig, som ingen Ligpræediken faar, betales til Kirken 8 Sk. danske, men bliver der Ligprædiken, faar Kirken intet. - For Vin og Brød at holde faar Præsten Kirkens Del i to Engholme, som kaldes Kirkens Holm og Ølgaardens Holm, og desuden $3 \mathrm{Rd}$. $4 \mathrm{Mk}$.

K o n g e ti e n d e n er hidtil hvert 3. Aar sat til Opbud, da Sognet selv altid har faaet den; disse Aar giver de $13 \mathrm{Rd}$. $2 \mathrm{Mk}$. derfor. At Kongetienden er sat saa liden, skal komme deraf, at $\mathrm{i}$ forrige Tider, da samme ydedes in natura, var fast Halvdelen af Sognet forskyldt, det kalder de at staa højere i Skylden, end de bør med Rette i Proportion mod andre Naboer; disse forskyldte var fri for at give Kongetiende. I lvorom end dette er, saa svarer de nu alle lige $\mathbf{i}$ Skyld, er og alle lige delagtige efter Ottingepart i Pengenes Afgift for samme Tiende. 
De fleste Gaarde i Sognet er kun maadelige i Bygning. $\mathrm{Pr}$ r s t e g a a $\mathrm{rd}$ e $\mathrm{n}$ ligeledes er ringe og gammel; jeg tror ikke, at den er fra Grunden ombygt siden Reformationen; for fem Aar siden stod endnu et Væagskab i en Mur af gammelt Bildhuggerarbejde med en af de første Præsters Arst Pedersens (d. 1679) Navn paa. Præstegaarden har næppe to Tredjedele Eng i Proportion mod de andre Beboere i Høyrup. Paa Præstens Riberhus Grund var nylig bygt et lidet Sted, af hvis Grund Ejeren aarlig skal svare til Præste. gaarden $1 \mathrm{Rd}$., saa og ved hver Forandring enten af Ejer eller Præst til en Slags Fæste 3 Rd. - Enken faar i Pension 24 Rd.

Hoyrup Sogn kaldes i alle gamle Dokumenter, som er for dette Seculum, Horup. Kirkebyen Hoyrup synes at have Narnet af sin Situation, da den ligger skraa op ad en Høj, saa at Monningen af det osterste Ilus er mestendel i Vandmærke med Grunden af det resterste, nemlig Præstegaarden. Norden til Vesten for Præstegaarden ligger Kirken, N. V. for Kirken er det hojeste af Hojen, en af de saakaldte Baunehøje . . . En liden Bæk, der fra Ribe- eller Gjelstoft Aa flyder som en Grænseskel mellem Høyrup og Arnum og ingen Navn har hos Mejer, kaldes Askorbok; paa Meyers Kort staar og Tyrsteth i Gjelstiofts Sted med en Trykfejl paa alle Karter et vice versa.

Til Sognet hører kun to Byer: Hoyrup og Arnum, og desuden Eenmark, to Halvgaarde, egentlig 6 Ottinger, Steensbcek, to Halvgaarde, egentl. 41/2 Ott., og Skorriderens Bolig ved Lindetskov. Denne sidste har ikke, saa vidt jeg ved, pro officio mere Land end til 
Hestetydring (Tojring), men har Tid efter anden taget scla meget Land af en nært liggende Hede under sig, at han høster mere end nogen Halvgaardsmand i Sognet, og dog har han hidtil hverken tiendet til Konge eller Præst.

Sognet bebos af 42 Lodsejere foruden en Del Landboeler, Toftmænd osv. Iblandt disse er $3 \mathrm{Sch}$ irckenborger Gaardmænd, som hver staar omtr. for 3 Tdr. 2 Skpr. Hrtk., en Riber-Huser, der har $1 / 5$ Gaard og staar for omtr. $1 \mathrm{Tdr}$. Htrk. og tilhorer en Konrektor Hansen i Ribe. De øvrige er Haderslev-Huser og er sat efter Plovskat, da der regnes 8 Ottinger til en Plor. Dersom en Plov gælder 8 Tdr. Hrtk. (efter Pontoppidan), saa er en Otting det samme som en Td. Hrtk . . Pala de fleste Steder heromkring regnes 4 Ottinger til en hel Gaard, men her i Sognet i Huyrup By 5 Ottinger og i Arnum 6 Ottinger dertil. Sognet har 73 Ottinger, hroraf de 66 er Haderslev-Huser, der altsaa udgnr $8^{1}+$ Plov; derforuden er Præstegaardens Avling, som har en halv Haderslevhus (aaard fri og $4:-$ Riberhus Gaard, hrilke blev i Provst Ferslevs Tid givne for Kaldets Ringheds Skyld, og staar i Jordebogen for 2 Tdr. 2 Skpr. 1 Fdkr., hvoraf betales aarlig til Ribe Anitstue 6 Rd. 2 Mk. og til Kirken 4 Rd.

Hvad Sognets nærværende Folkemængde, Avling, andre Næringsmidler og almindelige Tilstand er angaaende, da har jeg gjort mig saa meget mere Flid for at kunne give en nogenlunde taalelig Efterretning derom, jo mindre jeg in antiquitatibus eller physicis ved, som kan være værd at anføre. 
Personernes Antal i Sognet er 521, nemlig 220 af Mandkøn og 301 af Kvindekøn; af dem befindes i Høyrup By 102, i Arnum 378, i Eenmark 15, Steenshæk 17, Lindetskov 9. - Personernes Antal over 12 Aar er omtr. 370, Communicanterne 340; af dem hører nogle og 30 uden Sognet. De Dødes ungefehrlige Antal aarlig er 16, de Fødtes 18.

'Til en Otting i Arnum og Steensbæk saas ungefehr 20 Skpr. Rug, 9 Skpr. Byg, 9 Skpr. Havre, 10 Skpr. Boghvede; i Arnum hviler Jorden kun i 3 Aar. Der er og en god Del af saakaldet Sæed-Land til Byg og Havre, som aldrig hviler. Til en Otting i Høyrup saas 30 Skpr. Rug, 5 Skpr. Byg, 16 Skpr. Boghvede, 8 Skpr. Havre; der hviler Landet i 5 Aar. I Eenmark saas noget mere Byg, Rugen giver for 3. Kærvens Skyld ikke meget over 41/2 Fold, Byggen ligeledes, Boghveden kan regnes for 5 Fold. Alle Lodsejernes indavlede Rug tillige med Præstegaardens kan, naar Sæden fradrages, aarlig være henimod 7528 Skpr., Byg 2175 Skpr., Boghvede 3112 Skpr.

Naar til hver Person aarlig regnes 15 Skpr. Rug, 5 Skpr. Byg til Malt, 8 Skpr. Boghvede, saa bliver Sognets aarlige Mangel paa Rug 287 Skp., som skal købes andetsteds à 1 Mk. 6 Sk. Skp. $=65$ Rd. 1 Mk. 2 Sk., Mangel paa Byg 430 Skpr. à 1 Mk. 4 Sk. $=89$ Rd. 3 Mk. 8 Sk., Mangel paa Boghvede 1066 Skpr. à 14 Sk. $=154$ Rd. Havren foreslaar næppe til Fæsterne, de to Tredjedelen af Sæde-Havren, maaske 360 Skpr., købes hos andre à 12 Sk. $=87$ Rd. 3 Mk., Summa 396 Rd. 4 Mk. 16 Sk. Af dette tænker jeg, at der avles saa meget i Arnum, som Sognet hjælper sig med. Endnu 
er ikke regnet det Korn, som fortæres i Brændevin, koster aarlig $400 \mathrm{Rd}$. Der slagtes vel aarlig 50 Svin, til hver især at fede kan regnes maaske $16 \mathrm{Skpr}$. Boghrede $=116 \mathrm{Rd} .4 \mathrm{Mk}$. Sognets aarlige Udgift 913 Rd. 2 Mk. 10 Sk.

Den aarlige Afgift til Kongen eller i Maanedsskat, Skyld, Fourage, Magasin af Ottingen omtr. $12 \mathrm{Rd}$. Rd., Ekstraskat 310 Rd.; i hele Sognet er maaske 60 Rd., Ekstraskat 310 Rd.; i hele Sognet er maaske 3 eller 4 Lodsejere, som ingen Rente giver, Resten giver Rentepenge til andre Agre, omtr. 250 Rd. I Arnum lejer næsten hver Mand Hø paa den kgl. Pagtgaard Gjelstoft, ialt ungefehr for $180 \mathrm{Rd}$. Sognets almindelige Udgift er saaledes henimod 2649 Rd. 2 Mk. $10 \mathrm{Sk}$.

Derimod har Sognet en aarlig Fabrique af $\mathrm{K} n \mathrm{i}$ pling e r f for nærværende Tid knipler der 120 Personer, til hvilke der visse Kræmmere kommer nogle Gange om Aaret fra Tonder og skærer af; af disse Knippelpiger fortjener nogle, som nylig har begyndt, maaske kun 5 à $6 \mathrm{Rd}$. aarlig, men andre igen fortjener over 36 foruden deres Traad; man kunde altsaa regne middelmaadig pro persona 18 Rd., men naar man sætter endnu noget mindre, $50 \mathrm{Mk}$. lybsk eller $16 \mathrm{Rd}$. 4 Mk., bliver dog den aarlige Gevinst 2000 Rd. Desuden sælges Klyne og Kul fornemmelig til Smede i og ved Ribe, nok aarlig for $400 \mathrm{Rd}$.

Høyrup By har fornemmelig en herlig Mose Sonden for Byen i Omkreds henimod 1/2 Mil, hvor der graves som oftest 16 Klyner dybt, ja paa nogle Steder kunde der graves 24 , og samme er af de bedste og sorte Klyner. 
Af en Otting Land i gode Tider sælges aarlig Kreaturer for 14 Rd., hvilket $i$ hele Sognet kan udgøre 1022 $\mathrm{Rd}$. Altsaa bliver hele Sognet sat til Indtægt $3420 \mathrm{Rd}$.

Altsaa bliver Levningen af Ldgiften ikke saa liden til Jærn, Reb etc. og det, Bonden kalder Humle og Salt, hvorved han forstaar allehaande fornødne Viktualier, som hans egen Gaard ikke frembringer. Men da Bonden nu forst siden sidste Krægsygdom er kommen saavidt, at han kan sælge noget af Hornkvæget, saa har Sugnet siden den Tid hvert Aar gaaet meget tilbage. Der er næppe noget fattigere Sogn enten i dette eller nærmeste Herred. Mangen Mand sidder med Familie og Aftægtsfolk paa en Otting og samler ikke det Korn, som i hans Hus fortæres; hvis ikke hans Kone med nogle Lærepiger eller egne Born knipler, maa han lobe fra Stavnen.

HoyruI Haderslerhus Gaarde har tidligere haft ved deres Sluser en god Aalefangst, men i nogle Aar har den ikke kunnet betale Redskaberne; Aalene er af den Smag, at de bedste Riber Hvedeaal kommer ikke derved.

For nærværende Tid nyder kun tre $\mathrm{F}$ a $\mathrm{t} t \mathrm{i} g \mathrm{e}$ Underholdning af Sognet maanedlig henimod $1 \mathrm{Rd}$. hver, da Helligdagsfogderne kræver Armepengene ind, saa tidt det gores nodigt, og svares der af hrer Otting 4 Sk., af Toftmænd etc. 1 Sk.

Stændig S k o l e har hidtil ikke været i Sognet, kan ikke heller for de faa Beboeres Skyld være uden i Arnum. (iaardmændene der har jeg nu endelig faaet iil et vi et clam et pelleris ( 0 : med det gode og onde) at 
give efter Ottingspart en vis Del, enten de har Børu , eller ikke, til Skoleløn, som kan i alt beløbe sig til 10 Rd., da de og faar deres Born i Skole for halv Ugepenge, nemlig $1 \mathrm{Sk}$. dansk, naar de andre Toftmænd etc. giver 2 Sk. af hvert Barn, hworimod Degnen, der bor just i Arnum, for at holde Skolen, som vel og er hans vigtigste Pligt, er forbunden til, enten der er et eller 50 Born, at rære i Skolen hver Dag. Saalænge den gamle Degn lever, faar den unge, som fast ikke har andet end Skolen at leve af, efter Akkord af Lodsejerne.

I en Eng, som ligger til de 4 Haderslevhuske Helgaarde i Hoyrup, findes Rudera af en stor Bygning; der skal efter gammel Sandsagn have staaet en Herregaard. I Hofmands Fundatser kaldes den, om jeg mindes ret, Arrildgaard. Engen kaldes nu Abildgaards Kjorer.

Vodder Sogn. Indberetningen, af Nicolai (ieorg Overbeck, er dateret 22. Juni 1768.

Til P ræsteliste $\mathrm{n}$ giver han næsten alene den i Kirken værende Series pastorum; ellers fortæller han kun udførlig om sig selv. - Min, Nicolai Georg Overbeckis, Moder var Dorothea Sophie Rye, Datter af Nicolaus Rye, kgl. Majs. Ridefoged i Gram Herred. Min Fader's Fader Christopherus Orerbeck var Sognepræst for St. Nicolai Menighed ikke langt fra Staden Lüneburg . . . Min Skolegang fra forste Ungdom af har været udi Haderslev latinske Skole, hvorfra jeg blev dimitteret 1739; i samme Aar rejste jeg til Universitetet i Jena, hror jeg forblev til 1742. Derefter har jeg i mine Studenterdage altid konditioneret, forst hos $\mathrm{Hr}$. 
Poul Boldick, Færgemester ved Aarøsund Færgested, derpaa i København i Huset hos Hr. Frantz Heinrich Müller, Materialforvalter ved Holmen*), og Hr. Ditlev lindemann, Oberinspektør hos Grer DanneskjoldSamsøe, derefter nogen Tid timevis hos Kaptajn Lorentzen og Hr. Renteskriver Gold ....

K i r k e n kaldes St. Lauritz Kirke. Skal maaske være St. Laurentius, hvis Billede i ganske Korpus af Træ udhuggen med Risten staar i Kirken bag Prædikestolen. Efter gamle Mænds Sigende skal hans Billede ogsaa have staaet paa en gammel Kirkegaards Port, malet med den Overskrift: St. Lauritz in Wodder Kirke bygt til Are ... . Den er en lang og smal Bygning, 50 Al. lang, 101: Al. bred; er tækket med Bly. Den har et firkantet Taarn; et Spir; en liden Klokke uden Inskription. En liden Capelle paa den østre Ende bruges til Skriften. Den har Loft. Alteret er Billedhuggerarbejde, som bestaar af $\mathrm{X}$ (Christi) Lidelse og de 12 Apostles Billeder, slet Maling uden Inskription. Kalk og Disk er af Søly forgyldt, siges at være givne af en Krindeperson fra Bircklef By; paa Kalken staar: N. P. D. Messehaglen har Sognet bekostet paany 1735; hvad hver den Tid har givet dertil, er antegnet paa en Tavle opsat $i$ Kirken. Prædikestolen er til Hr. Jens Hermansens Tid An. 1655**) bekostet af Sognet; hrad hver den Tid har givet dertil, er ogsaa antegnet paa en Tarle opsat i Kirken. Den er Bildhuggerarbejde, be-

*) Han har altsaa varet Larer for den kekendte Apotoker og Skaber af den kgl. Porcellænsfabrik i Kobenhavn. Frantz Heinrich Müller.

**) Haupt siger (p. 439), at Prædikestolen er fra om-. trent 1610 . 
staaende af Christi Fødsel, Lidelse, Opstandelse, Himmelfart. Paa den nørre Side i Kirken lige over for Prædikestolen staar flg. Epitafium (det tages med i sin Helhed, da det indeholder flere Oplysninger, som Wiberg ikke har):

\section{Epitaphiurn over}

herunder hvilende

den hæderlige og vellærde, nu salige Mand

Hr. Damianus Johannsen,

Først Fældtpræst hos Hr. Grev Reventlou, sidst

Sognepræst for Wodder Menighed,

som døde i Wodder Præstegaard ud i sin Alders

40. Aar 1683,

sampt

den hæderlige og gudfrygtige, nu salige Quinde

Anna Pedersdatter;

Hans ægte kjære Hustru,

som dode udi sit Enkesæde sammesteds i sin

Alders 51. Aar 1698,

Hvis Herkomst var Provste-Blod,

Fra Sædeland indkaldet,

Hror de et Levned forte god,

Af alle Mænd befaldet;

Thi bor der ingen tvifle paa,

At Sjelene jo leve

Iblandt de Guds udvalte faa,

Sum Navnene her sveve,

Hvorfor man trolig ønske vil,

At Legeme maa romme

Af Graven op ad Sielen til,

Naar Christus han vil dømme,

Saa de iblandt de frommes Tal

Maa staa for Christi Trone

Og gaa udi Guds Naade Sal

At fange Airens Krone.

Oprettet

Gud til ære, Kirken til Prydelse, dem til Amindelse af

ders førstefødte Søn

16

J. D.

98 
Paa den nørre Side af Alteret sidder to Skilderier, som siges at skulle være Hr. Jens Hermansen (Præst her, d. 1666) og Hustru. Hr. Soren Jensen Bjorn (P'ræst her, d. 1758) og Hustru. De to sidste ligger begravne nederst i Kirken under Taarnet. Series pastorum staar paa en Tavle paa nørre Side i Kirken og er efter Sigende opsat af $\mathrm{Hr}$. Bjørn.

Kirkens staaende Indkomster er 5 Rd. 5 Mk., hvori tillige er beregnet Renter af $20 \mathrm{Rd}$., som Sign. Peder Bjorn af Astrup har givet Wodder Kirke. De staaende Udgifter er henimod 7. Rd.; til Brød og Vin gives ikkun 1 Td. Rug.

Præstega ardens Bygning afbrændte 1724 paa St. Karens Aften. Den er bleven opbygget 1725 af Præsten Jens Sørensen Bjorn og bestaar af Brandmur og er trekket med Teglsten. Den er ${ }^{1}$, Plov. Østen for Kirken ved Vejen til Gaansager ligger 14 Agre, som gaar fra Nor til Sønder, og kaldes tilsammen Prcestelokken, og S. Ø. for den er et inddiget Stykke Eng, som kaldes Hemmen, hvilke Agre og Eng hører til Præstegaarden foruden de, som ligger til den. 1/2 Plov.

Personernes Antal over 12 Aar er omtrent 240. - Gaansager og Bircklef Byer holder hver en Omgangsskolemester fra Michaelis til St. Peters Dag eller Paaske, til hvilke: Owed og Wodder Byer undertiden sender deres Børn.

Sognet har 4 Byer: Wodder med Præstegaarden, 23'4 Gaard, 6 Beboere; Gaansager, $5^{1}{ }^{1}: 2$ (iaard, 11 Beb.; Oned, 2 smaa Gaarde, 5 Beb.; Bircklef, 7 Gaarde 1 Otting, 15 Beb. Hele Sognets Plortakst: Ha- 
derslevhus Tjenere $10_{2 \times 4}^{173}$ Plov, Lygumkloster Tjenere $1^{3} \dot{4}$ Plor, Schackenborg og Riberhus Tjenere 9 Tdr. Hrtk.

V. for Bircklef By ligger et enligt Sted, som kaldes Wrace; det har en Beboer og har fra Arilds Tid lagt til Wodder Sogn. Ikke langt fra dette Wraae mod Norden ligger ogsaa et enligt Sted udi en liden Skov, som kaldes Statetskox, midt i Bircklef Bys Marker; fordi det saaledes er omkringgiven af Sognets Marker, kunde man slutte, at det tilforn maa have lagt til Wodder Sogn. Men om saa er, og naar det maatte være kommet derfra, derom haves intet. Det holder og med Kirkegang og Afgift til Roager Sogn. Mod Sønden ligger et andet enligt Sted kaldet Clmolle, hvis Marker paagrænses af Wodder Sogns Marker. Da fra dette Sted aarlig til Wodder Sogn gives Tiende Korns Penge, nemlig til Præsten 28 Sk. og til Kirken 14 Sk., det ogsaa paastaar Skolestader i Kirken, saa kunde deraf tages mere Anledning at slutte, det havde i fordums Tid lagt til Wodder Sogn, hrorom dog intet haves. Det søger ellers Kirke og Altergang i Scherrebek Sogn, og giver dertil Offer og Accidentier m. v. Derfor er det saa store Sogn blevet storre og det saa liden mindre.

Hvad $\mathrm{N}$ æringe $\mathrm{n}$ angaar, er den af maadelig Rug- og Bygland og ringe Græs Eng. Gaansager og Owed salar mest Rug, Bircklef og Wodder lidet mere Byg. Ruglandet hviler 3 a 4 Aar. Byglandet bruges aarlig.

Reisby Sogn. Indberetningen, der er stærkt makuleret og flere Steder helt ulæselig, skyldes vistnok 
Anders Pedersen Rador; i alle Tilfælde er den skrevet, medens han var Præest.

Til P r a stelisten er til Dels benyttet et Brev, skrevet af Præsten Peder Sørensen Wedel (d. 1691). - Den forste lutherske Prædikant og Sognepræst her . . var Hr. Soren Esbernsen [Ebbesen eller Ebberi]; han dode 1557, som hans Gravskrift udi Kirken klarligen udviser (se nedenfor). - Niels Pedersen dode 7. Sept. 1612, hrilket ogsaa hans Gravskrift melder om (se nedenfor). - Efter ham kom en kort Tid Jens [Hans] Regelsen, voceret til Seem. - Efter ham Jørgen Christensen, forrige Sognepræst til Seem Kirke, der skete en Tusk mellem disse tvende Præster, formedelst Hr. Jørgen var kommen, som berettes, i Unaade hos sin Øvrighed til Riberhus og derfor maatte kvittere samme Seem Sogn, men formedelst Øvrigheden til Haderslev [var?] ham derimod favorabel, blev han Sognepræst her i Hr. Jens' Sted . . . Hr. * Jorgen døde udi Præstegaarden c.'1740, bis maritatus, sed sine relictis liberis, velut omnes præcessores ipsius (gift 2 Gange, men uden at efterlade sig Børn ligesom alle sine Forgængere). - $\mathrm{Hr}$. Ole Jensen Colding ... døde i Foraaret 1655, ligger her i Kirken begravet udi en smuk, sirlig muret Grav (til dette er tilfojet: »men ingen ved den nu«). Om sig selv siger Peder Sorensen Wedel ... . kaldet til Reesbye Kirke, efter at den ædle Herre og strenge Ridder Hr. Key v. Olefeldt til Saxtrup [0:Ahlefeldt til Saxtorf] . . havde gunsteligen meddelt ogsaa mig foruden en anden Person mere sin Præsentations Skrivelse I Slutningen af sit Brev siger Wedel, at han for ikke at 
forbigaa noget, der vedrører hans Liv, omtaler, at han er godt forsynet med Børn (han havde ifl. Wiberg 3 Sønner og 2 Dotre), wsom er de allerførste Børn, der er ægte fødte her udi Reesby Præstegaard efter Reformationen", men forsigtig tilføjer han dog: salligevel jeg ej af nogen uægte Børn ved at sige, som her paa Steden nogenside er fødte udi Præstegaarden til denne Dag.. - Hans Efterfølger var Sønnen Soren Federsen Wedel (d. 1749), der svar først Kapellan hos Faderen i 6 Aar،. Af hans Børn (ifl. Wiberg: 7 Sonner og 4 Dotre) nævnes: Nikolay (Niels), Præst i Værum (d. 1779), Andreas, Præst paa Anholt (d. 1730), Peder, Herredsfoged i Lø Hrd., Søren, Tolder i Hjetting (Hjerting?), Susanne og Mette Margrethe, wbegge ugifte og værende i Ribe«, Anna g. m. Molleren Jørgen Friederich i Løgum, og Gathrine, g. m. Lieutenant Ditlev Diderich Koplau.

Den næste Præst Johannes Luffe . . . var født 1703*) i Oxwart (Oxford) i England, kom til Danmark (Ribe) i hans 12. Aar ... hans Opholdssted i hans Studentertid var mest i København, hvor han var Skoleholder ved en af Holmens fattige Skoler i Adelgaden. Han havde med sin Hustru 5 Børn: Ditlev Diderik, Søren Christian (d. 1792 som Præst i HorneAsdal), Cathrine Dorthea, Cathrine Margrethe og Anna Cathrine.

*) Ikke 1705, som Wiberg har. At 1703 er det rigtige, ses ogsaa af S. Abildgaards Læsning af hans Ligsten (Sønderj. Aarb. $1906 \mathrm{Pg}$. 105), som mærkelig nok ikke omtales her i Indberetningen under Kirken, hvor dog alle de andre Ligsten nøjagtig beskrives. 
Dernæst kom Anders Pedersen Radoor, ssom endnu er Sognepræst i Reisby«. Hans Børn af 2. Agteskab var: Hans, f. 13. Juni 1761 (d. som Præst i Brøns 1836), Peder, f. 8. Marts 1763, Elisabeth Marie, f. 13. Sept. 1764, og Sophie Hedevig, f. 16. Juli 1766 (se videre under Kirken).

Kirken. Da St. Maria Billede staar paa en gammel og ubrugelig Altertavle, saa er sluttelig, at Kirken er bleven kaldt St. Maria Kirke*). Den er med god Grundmur overalt og nogle Sten deriblandt. Den er tækket med Bly overalt, Taarnet ligeledes, og liar et smukt Jærnspir, hvorpaa er mellem den nedre Ende og Flojen eller Vejrhanen som en stor rund Kugle af Messing; Vejrhanen er ogsaa af Messing med et Kors udi, og ovenover samme forst et stort Kors og allerover'st tvende smaa Korser. Her er vel to Klokker, som hænger i Taarnet, en stor og en liden, men den store er for nogle Aar siden sprokken og ginske ubrugelig; paa samme staar: Soli Deo Gloria. Diese beide Klocke hebt Hr. Søren Pedersen Wedel. ...... in Husum Johan Hinrich .... Witz 1731 . . Paa den mindste og brugelige Klokke staar: Johann Henrich Armo Witz in Husum Soli De Gloria 1731 med fecit**). Kirken har Loft overalt undtagen neden i Taarnet og Sakristiet. Alteret er bygget af Sten og omklædet med Træ. Den nye Altertavle er sinuk og sirlig; nederst derpaa staar: Jesu Christi,

*) Kirken var indviet til St. Laurentius. Se Haupt I. p. 413 .

**) Den mindste Klokke, stsht af J. H. Armowitz, var der enduu 1847: den anden var aflest af en fra 1779 (Haupt). 
GudsBlod renser os fra alleSynder ...1677, ogenEngel paa hver Side, og Petrus og Paulus og paa hver Sideudgravet og udarbejdet. Ovenpaa staar vor Herre og Frelser afmalet som døbt af Johannes, derunder staar: Os bør at fuldkomme al Retfærdighed; ved Siden af dette er Frelseren uddelende Alter Sakramen. tet og hans 12 Apostle afmalet. Derunder staar: Tager og æder, dette er mit Legeme, drikker alle deraf, dette er mit Blod, og ved Siden af dette ligger Frelseren paa Knæ og stridende med Døden i Urtegaarden og 3 Apostle ... Længere op staar Frelseren som forraadt af Judas og bunden i Urtegaarden af hans Fjender... Ved den ene Side staar Moses med to Tavler, ved den anden Johs. den Døber . . . og Evangelisten Johs. . . Atter længere op hænger Jesu mellem to Røvere ... Jerusalem Stad eller Tempel. . . . Ved den ene Side deraf staar Evang. Matthæus .. paa den anden Marcus ... Endelig allernederst staar Frelseren opstanden fra de Døde mellem to Vogtere ... Desuden er Altertavlen hist og her prydet med mange EngleAnsigter. Der er to Kalke og Diske af Sølv forgyldte, det mindre bruges til Syge. Et gammelt Alterklæde af Fløjel, hvorpaa staar 1672. Paa Funten eller Døbestenen er udgravet nogle Menneskehoveder og Dyr; ovenover hænger ved en Jærnlænke et Værk eller Arbejde af Træ til at lukke for oven Døbestenen; paa samme Træarbejdè staar nogle Mennesker udgravede, en med et Haandværkstøj en andet med et Andet udi Haanden, men intet Skrift staar hos, hvem det skal betegne; Johs. den Døber staar ogsaa at døbe Jesum; 1671. Paa Prædikestolen staar Bebudelsen ..., Lejet 
i Krybben med Joseph og Maria, Hyrderne ..., Omskærelsen ...., de Vises Aabenbarelse af Østerland . . . $\left.1626^{*}\right)$. I Kordøren hænger Guds Søn paa Korset og paa Korsets Ender de 4 Evangelisters Navne. Item findes to Billeder, hvorpaa Maria med Barnet vises ..., hvoraf det ene i forrige Dage har været en Altertavle. Loftet i Koret er blaa farvet og afdelt i Stykker med rode Rammer og marmorfarvet inden i dem undtagen i det mellemste Stykke, derudi er et Hjærte afmalet med Vinger med den Inskription: Sursum cordis, Habemus ad Dominum, og i hver Ramme er 4 Engle-Ansigter. Paa den nørre Side ved Alteret findes en Tavle opslagen, saaledes lydende: "De Guds Born, som her i Menigheden have velvilligen præsenteret og udgivet af deres Formue Gud til Ere og hans Kirke til Beprydelse, særdeles til denne nye Altertavles Afmaling og Udstafering samt deres egen til Efterkommernes Amindelse og berømmelige Eftersagn, er disse efterskrevnes: (bl. Navnene findes Peder Sørensen Wedel og Hustru, 10 Rd., Morten Jamsen, Kirkeværge, 5 Rd., og Bennet Lassøn, fornemme Indvaanere i Havedt, og Hustru Maren Keyes Datter, 5 Rd.). Et Pulpitur, tæet ved Taarnet, er bygt tværs over Kirken. Paa den nørre Side i Koret en Tavle over Pastor Radors forste Hustru Else Marie Lund, gift 21. Novbr. 1754 (ikke som hos Wiberg $12 / 2$ 1752), d. efter 3 Aars og 5 Maaneders Agteskab 17. Maj 1758, begravet her tillige med sin sl. Datter. Dernæst ligger tre Trærammer i Gulvet i Koret, den ene over Præsten Niels Pedersen, d. 1612, den anden over

*) Ifl. Haupt er Prædikestolen fra 1612. 
Niels Pedersens Hustru Deelle, d. 16. . I Koret Ligsten over Peder Sørensen Wedel og Hustru og over deres Sønner Hans, d. 24/8 1766, 9 Aar, Præsten Søren Wedel, Nissenius Wedel, Præst i Døstrup (d. 1737), samt to Døtre, Susanna, Jens Lauritsens Raadmand i Ribe, og Mette, d. 9. Juli 1766, 29 Aar. Paa Kirkegulvet Ligsten over Benned Lassen af Haved, d. 2.. $\Lambda$ pril 1692, 78 Aar, og Hustru Maren Keyesdatter, som var f. i Apenrade og døde 5. Febr. 1696, 75 Aar. Paa Kirkegaarden 4 Ligsten, hvoraf den ene over arlig og velagte Mand $\mathrm{Hr}$. Niels Hansen af Rejsbye, d. 7. Oktbr. 1687, 70 Aar, og Hustru Anna Niels' Kone, d. 11. Decbr. 1716, 80 Aar.

Gaarde ligger her ingen af til Kirken, men her er en Mand i Sognet, som har en Eng, hroraf han aarlig betaler til Kirken $1 \mathrm{Rd}$.; derforuden er her en anden Mand i Sognet, som betaler aarlig af Landerier til Kirken 5 Rd., som i Kirkeregnskabets Bog aarlig findes og kaldes Jordskyld. Men naar de kom til Kirken, findes ingen Efterretning om.

$\mathrm{K}$ o n g e t i e n d e n, hvis Ejer er Kongen, er ikke anslagen for Hrtk.; den er hidtil hvert 3. Aar sat paa Auktion i Haderslev, og sidste Gang blev den en Mand her i Sognet paa hele Sognets Vegne tilslagen for 11 Rd. aarlig, men $\mathrm{i}$ forrige Tider har den undertiden kostet $20 \mathrm{Rd}$.

Præstegaardens Bygning bestaar dels af Grundmur, dels af Bind-Værk og er $i$ alt baade med Ret-Hus eller Sals-Hus og Ladehus 96 Fag; dens Plovtakst er ${ }^{13 \prime}{ }_{14}$ Plov. Til Præstegaarden ligger Ager og Eng ligesom til en anden hel Gaard i Rejsby, 
men anden Herlighed af Skov, Moser, Fiskeri eller Huse paa Præstegaardens Grund findes ikke. Af Successor skal købes hele Præstegaardens Bygning. Præstegaarden tilligger to Forbedelser i Kierbølling, til hver er 5 Nøds eller Kreaturers Græsser, og af hver svares aarlig til Præsten $6 \mathrm{Mk}$. Til den sidste Præsteenke, her var, svaredes $24 \mathrm{Rd}$. i Pension.

Gaardenes Antal i hele Sognet er 12. Beboernes Antal er 40, Præstegaarden undtagen. Hartkorn paa Riberhus Stavne er 67 Tdr. 3 Skpr. 1 Fdkr., Hrtk. eller Plovskat paa Haderslevhus Starne er 41,2 Plov, paa de grevl. Castelske Stavne 11/5 Plov, og Hrtk. paa Schackenborgs Gaard er $13 \mathrm{Tdr}$.

Efter gammel Tradition skal Rejsbye fordum have staaet længere til Vesten og da være kaldet Rijsbye af den Aarsag, at der nær ved Byen har været meget Riis og Skov, hvoraf endnu paa denne Tid findes Rudera, saasom Rødder af Træer og Hasselnødder etc., men for Flodens Skyld skal Byen være flyttet. eller hensat længere Øster paa og af Forflyttelsen er bleven fra den Tid kaldet Rejsebye, men nu kaldes Reisbye.

Saavel af Ager som Eng har Sognet $\operatorname{god} \mathrm{N} æ-$ r in $g$; dog siden her findes ved dette Sogn en meget god Eng og Græsning, altsaa har vel Engen Præferencen i Henseende til Næringen. Der saas Rug, Byg, Havre, Bønner, Arter, Boghvede og af disse Slags Sæd saas mest Byg.

I forrige Tider har vel Beboerne fisket en god Del smaa Havfisk til deres egen Fornødenhed, men nuomstunder bruger de Fiskeriet lidet eller intet. 
Saasom der ingen Skov findes her omkring ved Sognet, altsaa indfinder sig her meget sjældent og meget lidet af vilde Dyr, og helst henved Søkanten.

I Sognet findes en grov Smed, en Snedker og Bødker og to Skrædere og nogle Landsbyvævere. Af Fabriquer findes ingen uden den her i Egnen bekendte Kniplen af Kvindfolk.

Personernes Antal over 12 Aar er 309.

Foruden de saakaldte Husarme findes her paa nærv. Tid $5 \mathrm{~F}$ at $\mathrm{t}$ ige. Af de Fattiges Blok kan ungefehr aarlig indkomme 7 Rd., som deles af Præsten og hans Medhjælpere blandt de Fattige. For Resten besørger Sognet deres hver behøvende Fødevarer. Til Husarme kan aarlig indkomme 9 Rd. Rentepenge, hvoraf gives 4 Mk. lybsk til fattige Borns Undervisning.

Her er kun en Skole i Reisbye, hvortil alle Sognets Børn kommer. Skoleholderens Løn er, ligesom der er Born i Skolen til, thi han faar ugentlig 1 Sk. lybsk af hvert Barn, og kan Skoleholderens Lon i disse Aaringer regnes med ovenm. 4 Mk. lybsk til $19 \mathrm{Rd}$. Her holdes Skole hele Aaret igennem undtagen 4 a 5 Uger $i$ den travleste Tid af Sommeren. Det henligger til Præsten i Reisbye fra gammel Tid at udvælge og forestille Skoleholderen og Biskoppen at konfirmere.

Skjærbæk Sogn. Den meget knappe Indberetning, der er dat. 7. Aug. 1766, er skrevet af Pastor Hans Raer*).

*) Det er ham, som S. Abildgaard (Sond. Aarb. 190\%; p. 107) kalder en besynderlig Mand og en Menneskehader. 
Til Prastelisten, hvori der intet nyt er, er vedlagt en Del Dokumenter, hvoraf nævnes: a) Et Tingsvidne af 1546 om en Synsforretning mellem Poul Degns Jord og Hr. Thiøgy (Tyge eller Tage) Grumsen Thiener (Præst her, d. 1548). b) Et Tingsvidne af 1569 om tre Adelveje gennem ved Rasmus Ide, hvori Præesten Jacob Lauritsen (d. 1598) nævnes. c) Et Tingsvidne af 22. April $1639 \mathrm{om}$, at Præsten Søren Pedersen Hegelund (d. 1678) »lod læse for Dom og Ret Kgl. Mays. Dom saa vel Bispens Kending over Hr. Jaacop $i$ Scherrebek, at han skulde rome [rømme] sin Kald og Bestalling, saa var Hr. Søren begærendes af Kirkeværgerne til Scherrebek Kirke, at de vilde være tilfortænkte at forskaffe Hr. Jaacop ud af $\mathrm{Ka}$ pelanhuset*), formedelst Hr. Søren befrygted sig og ikke længere vilde være i Forlighed**) for hannem ... «d) Et tysk Bekræftelsesbrev af 3.April1700 paa den for Præsten Martinius Nissen (d. 1729) den 20. Juni 1 (6)1 givne Tilladelse at maatte holde Værtshus paa Præstegaardens Grund. e) Kaldsbreve for Præsten $A l$ bert Bogvad af 6. Juni og 14. Septbr. 1729. f) Forlis af 13. Marts 1730, underskrevet i Brøns Præestegaard, mellem Pastur Albert Bøgvad og Provst Peder Agidisen Dahler vangaaende en Del Dokumenters Extrade ring, som udi en 1736 mellem Bøgvad og hans Kapellan Michel Slilling værende Sag udi den holdte Provstret er bleven indleveret«...

*) Denne Kapellan Jacob... . har Wiberg ikke i sin Fortegnelse.

*ii) Hvad dette betyder, ved jeg ikke. I Kalkars Ordbog findes „Forligt“ $=$ Fælleskab. 
Om Kirken siges kun: Den har intet Hrtk., holdes vedlige af sin Tiende; tilliggende Jord, StolestadeLeje, Legata ved jeg intet af. Kongen ejer Kirken med jus vocandi. Dens Udgifter er til dens Vedligeholdelse og noget til Kapellanen.

Til Kirken ligger ingen $\mathrm{K}$ o n g e ti e nde, men Sognets Kongetiende har Sognet selv for en vis Afgift til Hladerslev Amtstue.

Soguepræsten har en hel Gaard paa Scherbek Mark, noget paa Giesing Mark og et lidet Stykke paa Huusum Mark . . . . Her regnes ikke efter Hrtk., men efter Ottinger, af hvilke 4 udgor en hel Gaard; hele Gaarde er her henved 50 ()... Her er mangfoldige Fattige, hrilke nyder rede Penge af Sognet i 4, 5 a 6 Kvartaler aarlig.

Sognet nærer sig af Agerdyrkning og Hestenes Opdract. Af unge Karle farer nogle til Skibs, hvoriblandt ogsaa Mænd i smaa Huse. De fleste Kvinder gør Kniplinger, hvorfor man til Arbejde maa have andets! eds fra.

Vedlagt Indheretningen er en Afskrift af et paa Latin affattet Skade fra 1416 om Ejendomme (Marker, Enge osv.) i Gasij (Gasse) og Gæsingh, hvori nævnes Johannes Jone villanus in Auerwith, Jacobus Nicolai i (Gasij og Johannes Jensen i Lustory.

\section{Gram Herred.}

Gram Sugur. Der er to Indberetninger, dat. 4. Novbr. 1767 og 26. Oktbr. 1768, af Pastor Anders Thorup, foruden en særlig Beretning fra Forvalter Kirner para (iramgaard og en refter $\mathrm{kgl}$. allernaadigst 
Befaling dat. 1 . Febr. 1690 underdanigste Specifikation paа Gram Præstekalds tillagte Indkomster, visse og uvissee, skrevet ca. 1700 af Pastor Frederik Hansen Firiis.

Af l'ræctelisten: Den sidste Præst før Reformationen var Niels Madsen. - Niels Simonsen (1. 1561; var fodt i Beck. - Sonnen Hans Nielsen (d. 1:92) . . Udi hans Tid blev St. Theocari Kirke, hvorhen vestre Sognet søgte, afbrudt og lagt til Gram Kirke. Fifter Sønnen Niels Hansens Død (1609) blev Kaldet bestyret ved en Kapellan Friderich (som siden blev Sogneprast til Spandet) i syv Aar*), indtil Sønnen Hans Nielsen [Lend] blev kaldet 1616 (d. 1656). Hans Gravsten findes overst paa Kirkegulvet op mod Alteret, med den Inskription: Her hvilerudi Herren Hr. Hans Nielsen, Sognepræst til Gram Kirke og Provst ndi Gram Herred, d. 28. April 1656 i sin Alders 63. Aar, samt hans to Hustruer, Anna S. M. Porses, Kannik og Sognepræst til Ribe Domkirke, hans Datter, d. . . Juni 1635, 31 Aar, og Anna S. M. Agidii Laur., Rektor og Archidiaconus i Ribe Kapitel, hans

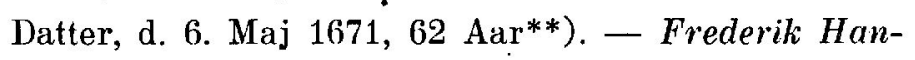
sen Friis (d. 1704) . . . I Kirken Gravsten over ham og hans tre Hustruer . . . Herforuden er og hans Epi-

*) Denne Kapellan Frederik næunes vel her i Gram hos Wiberg, men ikke under Spandet, med mindre det skal være den ovfr. (p. 90) nævnte Frederik Knudsen, som iflg. Wiberg blev Præst i Spandet 1606 eller 1616; det sidste Aar blev netop Hans Nielsen Lend Præst i Gram.

**) Ifl. Wiberg var han gift 3 Gange, men hans forste Kone, Gunder Nielsd. Bonnus, nævnes ikke her paa Gravstenene. 
tafium opsat i Muren i den nordre Side (med latinsk Indskrift; den saavel som Gravstenens Indskrift indeholder ikke noget nyt). - Daniel Clausen Blechingberg 1741 . . Paa den nordre Side i Kirken Epitafium orer ham og Hustru Kirstine Marie Friis, d. 29. Juni 1741, 64:4 Aar gl. Han havde med hende 5 Sunner og 2 Døtre, deribl. Fredr. B., Sognepræst i Ballum, (d. 1765), Major Gert B. ved Husar-Regimentet, og Claus B., Advokat i Bergen, (d. 1768). Peder Christensen Kraglund (d. 1750) . . . Epitafium over ham og Hustru Marie Elisabeth Sichelia, med hver. han blev gift 1707, hænger ved Daaben (i Taarnrummet), ivor deres Grav er; Epit. er opsat af Sønnen Hans Schack K. (Moderen var dengang endnu ikke død). Af deres Børn (3 Sønner og 4 Døtre) nævnes som endnu levende Sønnen Hans Schack K., Præst i Valløe (d. 1792 som Præst i Herfølge), og to J)øtre, Birgitte, g. m. Pastor Sevel [o: Seerup] i Faaborg, og Magdalene, g. m. Pastor Marcus Buch i Osterlinnet. - Om sig selv siger Anders Andersen Thorup. at han er født af Bønderfolk i Thy ..., har nydt privat Information i Ingstrup Præstegaard i Vendsyssel [hor Hans Jensen Gedsen dengang var Præst], indtil han 1720 blev dimitt. fra Aalborg Skole . . .; hans Opholdsted i Studenterdagene var i Ingstrup, hvor han gik Præsten til Haande med at prædike, indtil 1786, da han af Præsten [Henrik Hansen Kopp-Kuur] blev antagen til Kapelan ibid . . . . Af

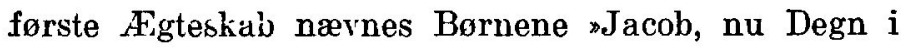
Fol, og Anna Catharina, g. m. Præsten Fogtmann paa Mandøe.* 
"Personalia og Specialia er mig ikke bekendt or. zogle af omme]dte Præster, men den Tradition kan seg alene anføre, som mig af mange gamle Folk er berettet or Fonten, som har fordum staaet i St. Theouri Kirke i Emdrupschow, at da Kirken i Hans Nielsen den førstes Tid blev nedbrudt, blev Fonten ført iil Nübelgaard og der hensat til vanhellig Brug at give deres Hunde Føde i, men som alle de Hunde, der aad eller labbede af samme Sten, blev stærkt galne, fandt sammesteds Besidder sig anlediget til at lade den hidflytte til Gram Kirke, hvor den endnu stạar nedsat ved den ostre Side af Vaabenhusdisren*;.

Kirken.... har et spidst Taarn, er belagt overalt laade paa Kirken og Spiret med Bly ...., har Loft, men i Taarnet over Daaben er Hvælving. Dens. ()rnamenta indvendig bestaar af to Pulpiturer, det ene indelult for det højgrevl. Herskab i den nordre Side. af Kirken, hvorpaa findes afskildret den Schackske Families 16 Aner, det andet er aabent for Almuen ned mod Tararnet. Kirken har to Klokker, af hvilke kun den ene er brugelig; den anden, som er en mindre do., har Briek og staar i Vaabenhuset paa Gulvet ubrugelig**). Alteret er af sirligt Arbejde temmelig. smukt malet og illumineret; paa Tavlen staar malet Christi sidste Nadvere med sine Disciple; paa den højre Side er Christi Daab, paa den venstre Christus i Urtegaarden styrket af Englen. Paa en mindre Tarle Christus crucifixus med Marie og Johannes:

*) Historien er gengivet i Danske $\Lambda$ tlas (VII p. 177).

**) Se Haupt I p. 403. 
ved Siden . . Foruden andet Billedarbejde, som præsenteres, pain Alterets Side de 4 Evangelister og alleroverst Verdens Skaber. Kalk og Disk er af Sølv forgyldt; paa Kalken et Sølvkrucifiks samt D. v. B. W. og M. v. B. W.; desuden et Vaaben og Aaret 1618; derforuden en skikkelig stor Oblatæske af Solv, hrorovenpaa er udstukket et imago crucifixi. Noch en Vinkande af Solv, som er foræret af Otto Diderik Schack 1677 . . Funten er to udhugne Stene satte paa hinanden; ovenover hænger $i$ en Iernlænke en gammel udarhejdet Træ-Krone, som øverst fremviser en Pelikan, som udtapper Blodet af sit Bryst. Paa Prædikestolen ... Bebudelsen, Christi Fødsel, Omskærelsen, Irremstillelsen i Templet, Daaben, alts. smukt Biiled-Smykk!-Arbejde, malet og forgyldt. Over Kordøren henger Effigies crucifixi, Billed-SniderArbejde. Paa nordre Side under Opgangen til Herskabets Stol hæenger et lidet Træ-Epitafium, hvorpaa øverst malet et Krucifiks, nedenunder et Egtepar i gammel Dags 1)ragt (det er over Melcher Seste og Hustru Katrine Fischers, beskrevet i D. Atl. VII p. 177 med de samme Ord, som staar i Manuskriptet).

Til Kirken hører intet Hrtk. eller tilliggende Fjendom, saasom Herskabet er Kirkens Ejer og holder den vedlige af sine Indkomster.

Jeg ved ikke, at Kirken har nogen staaende Udgifter uden det, som jeg aarlig nyder for Vin og Brod, som er i rede Penge 3 Rd. og 10 Skpr. Rug og 12 Skpr. Byg, og 1; Rd., som Provsten aarlig nyder i Visitatspenge; desuden udgives til Haderslev Skole aarlig 
i Travepenge 1 Rd. og 3 Mk. danske, hvilket ligeledes, nemlig det sidste, gives af Fohl Kirke.

Jus. voc. tilhører Grev Schack; samme jus voc. et patr. er a! Cihristian V. skænket og skødet til Hans Schack 1673, af hvilket Brev findes et fuldstændigt Kopi i min Libro datico.

Om Kongetiendens Hrtk. kan ingen Oplysning gives, eftersom Herskabet ejer Kongetienden, og for haade Kongens og Kirkens Tiende nyder Herskabet af hver Trave to Neg og Præsten ligeledes to Neg. Men som det ej er usance (Brug) her, at Bonderne fører Præstens Tiende, saa maa han nødes til at akkordere dem sin Tiende for, hvad de vil unde han:.

Prastega ardens Hrtk. er mig ubekendt. Dens hele Bygning bestaar af $93 \mathrm{Fag}$, noget grundmuret, mest Tavlmur, noget Bindings-Værk. Ager og Eng til den er kun lidet, nemlig 4 smaa Ottinger SædLand, hvortil 30 Læs Hø kan bjærges. Præstegaardens Eygning og deraf dependerende, men ikke Ager og Eng, købes ved Taksation eller i Mindelighed. Enken nyder p. t. i aarlig Pension 50 Rd. Præstegaardens Fata ses bedst af vedhæftede Dokument (Friss' Manuskript; se ndfr.).

De F a t tiges Antal er stort baade af Sognets egne og fremmede omløbende, men ingen Ligning har jeg forefundet over Sognet til de Fattiges Ophold, mindre noger. Anstalt til at hæmme de Fremmedes Overløh. Jer indsamles Aaret igennem i Tavlen 32 à $36 \mathrm{Mk}$. Iỵhsk til Uddeling hvert halve Aar til de Fattige. 
I Sognet er 7 Byer, de to største er Thiset og Kaslrup, dernæst er 3 middelmaadige, Grambye, Vesterlinnet og Emdrupschow; de to er kun smaa, hvoraf den one kaldes Schioldager og bestaar af 5 Beboere, den anden kaldes Harud (?) og har kun 3 Beboere.

Udi Sognet er $3 \mathrm{Sk}$ oler i de fornemste Byer, hvis Skoleholdere oppebærer af Gramgaards EjeI hver aarlig $10 \mathrm{Rd}$., og af hver $\mathrm{By}$ gives ungefehr andre $10 \mathrm{Rd}$. foruden en og anden ringe Villighed af Donderne. Le øvrige mindre Byer eller Torper lejer sig selv en Skoleholder. Herskabet kalder Skoleholderne til de oprettede Skoler.

Ved Geelsbro er nylig bygt paa Gramgaards Bekostning en Bro over Aaen. Over Aaen ved Gram ex tvende Broer.

Her er to Herregaarde, Gramgaard og Nübbelgaard, desforuden en kgl. Pensionærgaard Gjelstoft.

Gramgarid menes at have sit Navn og Oprindelse af Kong Gram; den har i forrige ældgamle Tider staaet en Fjerdingsvej Vesten og Norden derfra 1 sondre Side af Skoven, som endnu kan ses nogle Spor og Kendetegn af, og kaldes det Sted derfor endnu Gammel Gram, men hvis Tid den er flyt, vides ej. Slotshygningen bestaar af 3 sammenbygte Fløje . . . og er solitl Grundmur, tækket med Hultegl, to Etager foruden underbygte Kælder og Køkken. Norden for paa samme Plads, dog adskilt ved en Bro over en Arm af Aaen, er to Bygninger, teglhængte, det ene fornemmelig Bryggerhus og Borgerstue, det andet indrettet især til Tingstue. Paa en stor Plads, adskilt derfra ved en anden Bro, ligger en meget stor, 
vid $\operatorname{sg}$ hoj grundmuret Lade med behørige Stalde og Øksnelıuse; der lidet Øster for ligger Meier-Hoffet, hvor Forpagteren p. t. bor. Gramgaard er en komplet Hovedgaard, bestaaende af 30 Plove, som kaldes. gamle (irammer, og 16 Plove, som kaldes nye Grammer, hvilke Feltherren siden har kobt af Kongen*).

Nïbel har været tilforn 4 Bondergaarde, som af Johan lieventlou, da Herre til Gram, skal være opbrurit og som en Meier-Hof lagt til Gram og siden udi Brodre-1)eling er udskiftet fra Gram i Christophe, v. Buchwalds, Johan v. Buchwalds og Dionysii v. Podewils Tider. En adelig Familie kaldet de Vognsfleeter har ejet det, som solgte det til Dr. Koch i Aabenraa, hvis Son Justitsraad K. for en 8 Aar siden (ca. 1759) har afhændet det til Fru Anna Sophie Rantzow Grevindr af Schack kort for hendes Død, som igen testamenterede Giaard og Gods tillige med hendes andre. Godser til nuv. Greve Schack. Nübbelgaard bestaar af 9 Plove; de underliggende Bonder er mest i Emdrupschow og 4 Bonder i Thiset Sogn.

Gielstoft, deraf har den halve Part i forrige Tider lagt til Nübbel; paa den anden halve Part boede 3 Bonder, som var kgl. Majs. Tjenere, og et Sted derforuden kaldes Moeshuset.

*) Af Forvalter Kirnens Beretning, der indeholder en nujagtig Specifikation af alt Bondergodset, der horer til Grangaard og Nybelgaard, anfores kun: (iammel (irammer Bonlergods, som er ansat for 30 Plove, til den kgl. Cassa ud i Rendsborg maanedlig à Plov 2', ${ }^{1}$ Rd., ihvorvel her $\mathrm{i}$ forrige Tider skal vare deraf solgt 10 Plove, som er ikke afskrevne... 
Der ligger en Del store Stene paa Kastrup Mark, :som kaldes Gammel Kirke, hrorom er den Tradition, at de er samlede her $\mathbf{i}$ Begyndelsen i den Absigt, at Kirken skulde have staaet sammesteds, men blev dog

- intet al, eftersom alt, hvad der blev opbygget om Dagen, det blev forflyttet om Natten hen til det Sted, hvor den nu staar (Fortællingen er gengivet i D. Atl.).

Sognets leedste $\mathrm{N}$ æ $\mathbf{r}$ ing bestaar i Pløjen og Kniplen; hvad Plormandens Sæd og Avling bringer ham int mere end til nodtørftig Ophold, kan han afsætte til Knippelspiger og smaa Folk, som udgor den storste Del ai Husets Lemmer. Rug og Boghvede er det meste, som arles her, af Byg og Havre saas kun en ganske ringe Del, saasom Landet er af den Beskaffenherl. a: Rugen vil ikke vel gro efter Bygget. og naar I.andet har givet tre Kærver Rug af sig, kan den ej bere noget Havre. Bonderne bruger mestendels Jorden 4 Aar og lader den hvile 4 à 5 Aar; nogle faa Agre er Sæd-Land.

Personernes Antal over 12 Aar er 880 .

Her er nogle Raadyr; engang imellem fanges et Vildsrin.

Af Friis' Beretning anfores:

Lesatte $\mathrm{G}$ a a $\mathrm{r}$ d e er henved 40, ubeboede 16 . Offer af store Fester, som er af og til mere eller mindre, besynderlig naar Herskabet ikke residerer, kan belobe sig hier af de hoje Fester $16 \mathrm{Rd}$. - St. Hans-, Jule- co Pauskerente. Heraf falder intet udi Gram Sogn til Præsten, men sidst i Maj i Pinsedagstider falder Smørburd og Kvægtiende, nemlig af hver Ko, 
som er malket, 2 Pd. Smør, det 30. Lam til Præsten, af hvert Føl, Kalv eller Gris en Hvid; Brød og Ost, som gives tillige med Smørret, som er ulige af nogle Gaarde, eftersom de af Arilds Tid givet haver. Og under Degnen 3. Part af Smør, Brød og Ost.

' r æ stega arden til St. Thogers eller Emdrupschow Kirke, som ungefehr for 100 Aar siden er blevet afbrudt og annekteret til Gram Sogn, har efter de Gamles Beretning været den vesterste Gaard udi Emdrupschow, som er siden lagt under Nübel, med hvad Ret vides ikke.

Gram Præsteg a a rds Grund er formedelst Gramgaard, som ligger straks hos, meget indkneben, san Præsten maa hyre og leje Græsset og Foderet. andensteds til det $\mathrm{Fæ}$, som han føder om Vinteren. Seks Agre og fem Blokke findes paa Syndervang og. har ligget til Præstegaarden af Arilds Tid. Noch 4 dobluelte Agre smstds., som af Feltherre Schack blev udlagte til Præstegaardens Ager, men 1667 blev indkoblet til Gramgaard. Noch findes en liden Kobbel eller Lykke S. og V. Gram Kirke, som 1640 udi Marskalk Dionysii v. Podewils Tid blev udlagt til Præstegaardens Grund og Ager, som da Vesten samme Kobbei hlev indkoblede til Gram. Noch findes Norden ved Kirken et Stykke indelukt Land, som kaldes. Kirkemaj, hvorudi kan saas en Td. Byg og bjærges ungefehr en halv Snes Læs Hø, ligesom Aarbøret er til. - Et Stk. Agerland paa Kastrup Mark kaldes. Prcestejord eller Prcestetoft.

Dokumenterne er her i Sognet forringede saavel sorr: i ganske Haderslev Hus Lehn siden Krigstid 1659, 
d. Folkene er næsten uddøde her af Sognet (nemlig 7) 2 udi det Aar), hvorudover en Part af Gaardene er endnu ikke besatte, og findes paa Nübel Stavne 8 Gaarde, som siden 1673 er blevne øde foruden Nübel Sædegaard, hvoraf Præsten ingen Tiende nyder og derforuden paa nogle Aars Tid ingen Offer har bekornmet. Ved Mageskiftet, som skete 1640 udi Dionysii v. Podewils Tid, er Præstens Enge udlagte med de andres i Gramby for en fremmed Grund eller Mark kaldet Skovkrog, og er de 4 Stkr. Aamaj Eng, hvorpaa kan avles aarlig, ligesom Aarbyrdet er, mellem 10 eller 11 Læs Hø.

Ellers ligger for Nübel Mark ungefehr en god F.jerdingsvej derfra et Stk. Eng. kaldet Buxholm, hrorpaa kan avles med Besværing mellem 6 og 8 Læs Hø.

Et gammelt Pergaments Lovshævd, som er forhvervet 1518 Sondagen næst før Vor Herres Himmelfartsdag af Sognepræsten Niels Madsen, lyder [hele Dokumentet er afskrevet] . .. disse efterskrevne Jorder og Enge for ret Præstejord til Gram Kirkes Præstegaard, som dertil ligget haver med Rette, som er forst et Stk. Jord paa Kastrup Mark, kaldes Proestejorci, liggende op til deres Jord af Gramgaard; item 2 Stkr. Eng paa Nübelmark, kaldes Bucksholm, og en anden, kaldes Bromaj; item en Toft Vesten Gram Kirkegaard og en Østen Kirkegaarden og en Eng, kaldes Kirkemaj; item en Toft Vesten Præstegaarden ....*

Videre Dokumenter Præstens Indkomster vedk. har jeg ingen forefundet, men berettes der af de gamle, at de papistiske Præster, som var her udi 
Reformationens Tider og ikke vilde annamme den luth. Lærdom, rejste bort og tog Dokumenterne med sig....Bronaj Eng har de, som har boet paa Nübelgaard, indkoblet, med hvad Ret vides ikke, eftersom ingen uden Kongen kunde abstinere samme Eng fra Præestegaarden.

Udi de 4 Aars Tid indtil 1694 har Hoffrath Mechelburg, som boede udi Schleswig og holdt sin Forvalter paa Nybel, aldeles intet givet os af Nybelgaard, uanset vi in concurso creditorum, som blev holdt efter sl. Wulf Henrich $v$. der Wisch 1680, blev tilkendte at skulle nyde af Nybel til vores Offers Gebyhr aarlig $4 \mathrm{Rd}$. Og omendskønt jeg nogle Gange skriftlig har Mechelburg derom gjort Anføjning, blev dog intet os givet af vores Gebyhr, men derforuden med været os frataget et tiende Lam 1693 ved hans Foresatte, hvilket Lam ved Lod mellem hendes grevl. Naades Forvalter og mig var os tilfalden, hrorpaa jeg har taget Thingswinde til Gram Herredsthing 28. Septbr. 1694, drog bort i det samme uden nogen Satisfaktion til Lym (Lygum) (iloster. 1694, da Christian Ernst Frobos antog Nybel, impationeret (?) han sig straks vores resterende Tiende af Gielsbro Mølles Mark, item noget af Emdropskov Mark, ungefehr det hele regnet paa 11 Skpr. Rug, og der jeg gjorde Anfordring til ham, svaredes der, at han havde købt alting til Nybel. I lige Maade har han 1695, der Christian Moller kom fra Møllen, forholdt os vor Tiende af samme Mark. - 1699 har bem. Proprietarius paa Nybel taget vores Tiende bort af Skovkrog Mark . . under den Prætext, fordi Bonden nylig var bortrømt 
derfra; truer derforuden at ville, som dette Aar, have i Fremticien Part i Tiendelammene, som ellers tilkommer Kirkejl ng Præsten.

Anlangende den Tiende, som min Formand i 40 Aar og mig selv paa 43. Aar er given af Gielstoft, da truer Detlef Outzen, som har Gielstoft i Pension, i sit aabne Brer, at naar det ham behager, vil han forholde Præster. sin Tiende af Gielstoft, beraabende sig paa sit Pensionsbrev, hvorved han formoder sig at være fri derfor. - Det Stk. Eng, som af Ditlef v. Buchwald 1660 blev udlagt i Gielstoft Rorkicer til Præsten for sin Rettighed af Mosehuset ved Gielstoft, som Ditlef v. Buchwald har afbrudt og bragt til Gielstoft, har Ditlef Outzen for nogle Aar siden fra Præsten borttaget uden noget Vederlag.

Findes vel mere, hvorudi Præsten kommer til kort, og Præstegaardens Grund er meget bleven forringet ved Mageskifte og Forandring, som den ene Tid efter den anden her ved Stedet er sket.

Kirkens Skov, som i Ufredstid 1657 og 58 blev forhuggen, og siden af Vinden mest omkast Tid efter anden, e $\jmath^{\prime}$ bleven ganske øde, saa hverken Kirken eller Præsten kunde, have nogen Hjælp deraf . . . .

3. Fros Herred.

Hyguu Sogn. Indberetningen, dat. 1. Jan. 1766, er skrevet af C. A. Dyssel.

Ved F'r stelisten er intet nyt, uden hvad Christian Amold Dyssel fortæller om sin Bedstefader, Fader, Onkler og Tanter samt sig selv, men det er altfor udførligt til at kunne medtages*).

(* Se Personalhistorisk Tidsskrift 6 R. II. 
K i r k e n . . . St. Laurentii Kirke, har et stort, fra Grunden af firkantet Taarn med en høj Spidse, har i samme Taarn to gode Klokker. Paa den større staar: Claus Asmussen in Husum hat mich gegossen, aus deln feur bir ich geflossen. Gloria in Exelcis Deo. Deo et ecclesiæ Hugomeneanæ Ao. MDCLXXXVI. Pastore Petrs .Tacobi Haderslebiano, AEdilibus Canuto Jani e! Latgone Callovii. Paa den mindre Klokkes søndre Sine staar: Me fecit Johan Heinrich Armowitz in Husum: og

Giv, Klokko, saadan Lyd, at Hjærterne kan bryde Suk og Bønner ud, soin sødt for Gud kan lyde. Lad hvert et Klemt, du slaar, paaminde os derom, At Tiden lakker snart mod Herrens strenge Dom.

P:amind, som du est støbt, saa skal og Aanden støbe Hver Sjæl i Ordets Form, paamind dem, at de løbe Med Iver til Guds llus, indtil de deres Tro I Lolws skifte kan med ævig Fred og Ro.

Paa den nørre Side staar: Deo et ecclesiæ Hygomeneanæ Ao. MDCGXXXIII. Pastore Petro Jacobi Hyg $)$. Aidilibus Petro et Thoma Mathiæ *). Kirken er udvortes vel bygget af lutter Kvadrat-Kampest $3 x$ til Triget, som alt er blybelagt; indvendig er den med dubbelt Joft, et ovenover Bjælkerne og et nedenunder Bjælkerne, hvilket er panelet og med Oliefarve

*) Medens den store Klokke endnu findes, er den mindre der ikke mere; se Haupt I p. 408. 
smukt malet, ligesom og Pulpitudet (!), Prædikestolen og Alteret*).

Indlomstor har Kirken ikke uden den bare Kornticnde af Sognet, hrorved den dog har en god samlet Kapital henved 2000 Rd. i Rente og Behold.

Sk olerne er her to, den ene i Kamtrup, den anden i Hygom; begge har Kirken af sine egne Midler orbygget for en 18-20 Aar siden. Hver har en Skoleholder, scrn $A$ mimanden i Haderslev efter Præsternes Forslay beskikker. Til deres Løn kontribuerer Kirken af sine Midler hvert Aar 14 Rd. og desuden holder Skolehulsene vedlige.

I) e $\mathrm{g} \mathrm{n}$ e $\mathrm{n}$ beskikkes af Biskoppen i Ribe; forhen har en Skole Person fra Ribe været Løbe-Degn her til, men nu er en, som er den anden i Tallet, der er ordentlis beskikket og bosiddende i Hygom, som er ustuderet og giver aarlig til Ribe Skole $7 \mathrm{Rd}$. Han er for nærv. Tid skoleholder for Skolen i Hygom, nyder af de 1t Rd. de 16 og formedelst et Legatum aarlig af Præsten i Hygom 3 Rd. 2 Mk.**). Fundationen forSkolen i Hygom er dat. 16. Juni 1745, for Skolen i Kamtrup 7. Dechr. 17亿5.

T i r g h u s e t, hvor Retten for Fros og Kalfslund Herrede: holdes, er i Byen Hygorn bygget paa Herredernes Bekostning for en 9 Aar siden. Herredsfogden, som tillige er Ridefoged og Kancelliraad ved

*) Den nuværende Altertavle er fra 1811, malet af J. C. Lund (Kvinderne ved (iraven).

**) Det er ifl. Khode, Haderslev Amt, p. 449, Præsten Ancker Christensen. Svendstrup. 
Navn Heinrich Daue, bor ogsaa her i Byen. Rettergangs maaden er paa Tysk.

P $\mathrm{r}$ s t e ga a rden er som andre i Haderslev Hus Amt af kgl. Naade fri; den købes af Successor enten ved Akkord eller, naar den ikke kan træffes, efter lovlig Taksation, og den vedligeholdes af Præsten selv. Prrestegaarden købte jeg ved Akkord af min Anteccessc.rs Arvinger uden nogen Taksation og gav for den 823 hil. . . . Dernæst gav jeg dem for den fulde Sæd, soin da var lagt baade Vinter og Foraar, item Græs og $\mathrm{H} ø$ samt deres Part af Naadsensaaret, 300 Rd., i alt 1123 Rd. . . Den har ingen Særhuse eller Tillæag uden et Hus paa Gaden, som dog af Successor kobes efter Taksation. Avlingen af Korn og $H_{x}$ til Prastegdarden nar her som flere Steder den heklagelige Skæbne, at Ager og Eng ligger udspredt mellem og i Fællig med Bøndernes. Jeg har maalt alt det . Agerland, jeg dyrker, og har befundet at have over $782,370 \square \mathrm{Al}$., men samme Jord er nu saaledes i smaa Stỵkker blandet mellem Bymændenes, at det vel ligger over 70 Steder, og saa har det og med det lidet England, her er. Paa Avling har Præstegaarden for en 20 Aar siden været dobbelt saa stor, som delı er nu, nemlig 5 Ottinger; men da har Sognepræsten Hr. Jacob Pedersen overladt Halvparten af hele Præstegaardens Jorder, 21/2 Otting, til en af sine Brodre, som da var Tingskriver her og havde et jordløst Sted, hvorimod saa skulde gives 10 Rd. aarligt tii Amtshuset i Haderslev, Kongen til Interesse, og 20 Sípr. Rug til Præstegaarden. azrligt; det var i 
Hens. til Efterkommerne altfor stor Afgang mod saa lidet ct Vederlag.

Folkemængden er ikke højere end 400 Communicanter, thi deres Tal, der nu betaler Ekstraskatien fra 12 Aar af, er ikke højere end 430 præterpropter.

Byerne er Hygom, har 16 Decimanter, 371/4 Otting, Harbye, 18-461/4, Fasted, 15-37, Kamtrup, 5-14, Brostrup, 11-23,4. For sig selv liggende Steder: Barslund, 2-4, Kiemsgaard, 1-3, Store Knurborg og Lille Kunrborg, tils. 3-5 $5^{3}$, Beenborg, 1-3', Otting, 1-4, Holm, 2-33.4. Noch gives her i Sognet 7 særskilte Landboelshuse foruden en Del Aftægtsfolk, IIusfolk og Inderster.

Af Navnet Hygom giver Præsten en kostelig Forklaring:

"Hygom siges at være sammensat af Verbet, jeg hỵkker, og Præpositionen, om, og ved et eneste Bogstavs Forandring bliver Hykom let til Hygom; jeg hykker om, hykker omkring, maa flytte og fly i Fjendetid fra Hus og Bopæl mange Gange, men idelig kommer igen til min Bopæl i armelig Tilstand. Hvilken Flytten og Flygten og Hykken omkring Bønderne her i Sognet ogsaa meget ofte i Fjendetider skal have fristet, som sidste Gang endogsaa skal være sket 16.59 om Vinteren, se Appendic. til Ribe Stifts Fundation p. 21, hvor jeg den daværende Sogneprasts Ord har anført."

Herregaarde er her ikke, ikke heller er her mindste Spor af, at her i gamle Tider har været nogle. En Gaard er i Byen Harby, som hedder Abbedskicer, hror 
menes en Abbed har boet og deraf skulde have Narn. Jordens og Grundens Natur og Beskaffenhed er mest Hedeart, skarp sandig og stenig med gul Ler under sig og sine Steder stærkt grov Al straks under den tynde, sorte Jordskorpe; ved Harby gives et Slags Mergel eller Hvidler, som bruser og solverer sig straks i Vand og er god til Godning. Marken bruges her i 5 Aar efter en Gode og hviler igen 5 Aar.

Avl og Sæd er her mest Rug; den bedste Avl, jeg ved her, var $\mathrm{i} 1753$, da her avledes 5100 Traver Rug, $2(140$ Tr. Byg, 640 Tr. Havre og over 1600 Tdr. Boghvede. Ved det Aan kunde noget nær lignes 1764. Men nogle derimod er ringere, saasom 1750) og 1762, da der ikke avledes over 3500) Traver Rug, $760 \mathrm{Tr}$. Byg og 400 Tr. Havre og saare lidet Boghvede. Det naerv. Aar 1765 var i Travetal af alle Slags Korn endnu ringere end de forrige ringe. - England og Grasning gives her kun lidet af. Skovbund er her, men Skov, som her har stauet stæerk af Eg og Bog fordum, er her nu intet videre af end saadant, hvoraf fornødent Gærsel og Staver kan haves. Brændselen er Hedetorv og Klyne; det sidste bekommes af en stor og uudtnmmelig Mose, som Fæsted By og Mark tilhørende ligger langt til Vesten til hen imod Ribe.

Bjærge eller Begravelseshøje gives her ikke; paa vores Mark alene ligger en 3 à 4 Høje sammen, som kaldes Ting-Hojc, hror i gamle Dage er under aaben Himmel holdt Ting og Ret.

Teglbrænden med Mursten er ved hver By, og her brændes gode Mursten, saasom der gives godt Ler der1il, ja endog Pottemagerler til rode og glasserede Kar; 
har og boet for kort siden i Brøstrup en Pottemager, som har brændt gode Kar.

. . Hver Dreng eller ung Karl vænnes til fra Ungdom af at kunne hugge med en Økse og gøre, hvad hehores i en Gaard til Gaardsbrug som Grebe, Skovle, Træsko, Plov, Harve og Vogntøj.

Straks ved mellem Sognet og Lintrup ligger en Kongen tilhørende Vandmølle, Schicerrebcek kaldet, hvortil Sognet, saavidt det er Haderslevhusisk, er mollepligtig.

Kreaturer som Heste, Fæ, Faar og Svin falder her ikke saa stort som i Nørre-Jylland, skønt avles og opdrages nok deraf, og drives stor Handel dermed af Benderne i alle Byer. Vel er Opsynsmænd i hver By, som giver Attester med det, som sælges og købes under deres $\mathrm{Ed}$, og Grænse-Kontrollører satte, men om Hs. Majs. Fordel derved noget befordres, eller om Toldsvig ikke mere tryg derunder øves end hæmmes, det er et andet Sporgsmaal; saa meget er at befrygte, at megen Mened sker.

V ild e D y r er her som i andre Skovegne, raaeDyr, Harer, Ræve, Ulve og Vildsvin, Grævling, Oddere og Morer (Maarer), men Rotter ingen. Feder-Vildt ligeledes, Gæs, Ender, uhr-Høns, agger-Høns, Pomerantz-Fugle, Beccasiner, Kramsfugle, Skovduer og Storke, som er ganske sorte med rødt Næb og lidt hvidt under Brystet, som jeg selv har set i Aar et Par af.

Fol Sogn. Indberetningen, dat. 22. Oktbr. 1767, er af Pastor Hans Christensen Højer. 
Til Præstelisten: Efter højædle og højærv. Hr. Biskop Blochs Ordre har jeg gjort mig al Umage: for at finde Præsternes Navne, som har været i Fohle Sogn, skønt der findes ingen Kirkebog, som der dog maa have været, hvilket sluttes deraf, da sl. Provst Chrystalsin i Bevtoft har sagt mig, at sl. Provst Kragelund i Gram, som var min Formand i Embedet, havde vist ham $i$ en skreven Bog, at da Pesten grasserede i Fohle Sohn, kom to Mrend ind $i$ et Hus i Ganderup, hvor de saa to siddende ved et Bord rokkende frem og tilbage, hvorfor de mente, at de havde været levende, men da de saa til, stod Hunde under Eordet og aad af dem, hvilket maa dog være skrevet af en Præst i Fohle. - Den første, jeg finder nogen Efterretning om, er Anders Jespersen, som har til Vitterlighed 1591 6. Septbr. underskrevet et Mageskifte mellem sin Nabo Soren Jespersen og en Mand udi Ganderup. - Jesper Andersen, som ses af et Forlig mellem ham og Jens Sørensen, Herredsfoged i Frøs og Calslund Herreder, ang. en Vej og Forte gennem Præstegaarden til Østermark og Skov, dat. 16266. Juni. - Berthel Jespersen, som ses af et Tingsvidne, som formeldte Herredsfoged har taget om den Vej og Drift gennem Præstegaarden, underskrevet af Hr. Berthel 1647 1. Juli, hvorudi han tillige skriver, at hans sl. Fader døde af Pesten. At samme Hr. Berthel skal være dod af Pesten, melder Traditionen saaledes: Da en Mand i Ganderup skikkede sin Søn til Haderslev efter en Hest, som enten var ham fratagen eller var laant en anden der, kom samme vel frem med Hesten, men af Pesten angreben, hvorpaa 
hans Moder blev syg og Berthel kaldet til at betjene hende, som spurgte, om han maatte ikke uden for Huset ved Vinduet consecrere Sacramentet, men blev svaret, at han skulde gaa ind i Huset at forrette sit Embede, hvilket han og gjorde. Men som han mærkede sig af Pesten at være angreben, gik han ikke hjem til Præstegaarden, men ind i Kirken. Saasnart hans Kone fik det at vide, gik hun og til ham i Kirken, og som hun endeligen, ihvormeget han forbød det, vilde tale ham, sagde han, hun skulde gaa først hjem at skikke deres Børn, som var tre Døtre, til Hygum, som og alle levede og to af dem siden giftede i Fohle Sogn, den ene i Fohle By, den anden i Ganderup. Han dode 16555 paa Fastelavnsmandag, som er optegnet $\mathbf{i}$ en Bibel af Christian IV og ejes af en Mand i Obbekiær, men har vist tilhørt Kirken og maa være kommen bort ved et af Hr. Berthels Børn. - Hans Pedersen Weibel [1655-99], som ses af en Forskrivning, hán har givet Bagge Baggesen i Ribe paa nogle Penge, som Hr. Berthels Børn var ham skyldig efter deres sl. Fader. Han har været en særdeles besynderlig Mand. Han rejste engang fra Hus og Hjem imod Juleaften, uden at nogen vidste, hvor han var, hvorfor hans Kone maatte have Præsten af Hygum til at prædike og tage Offeret. Ham blev Anders Hvidding, en Præstesøn fra Ribe, adjungeret, som ægtede Hr. Hans' Datter og døde før sin Antecessor [1692], der døde først 1699 . og hans Hustru Margrethe . . 1703 ..., hvilket ses af en Sten, som er lagt paa dem paa Kirkegulvet . . Anders Hviddings Enke blev siden gift med Peder Hygom, Tingskriver 
i Frøs og Calslund Hrdr. - Laurids Fogh $[1692$ til 1703] lod Præstegaarden, som tilforn laa adspredt paa tre adskillige Steder, nemlig Indhuset, Øksenhuset og Laden hver for sig, sammenbygge udi en Firkant indlukt, men Forseelsen var, at den blev saa liden, at den ej kunde rumme Præstegaardens Avling, som efter Skønsomhed bestaar præter-propter af 8 Tdr. Hrtk. Men som det behagede Gud, at Præstegaarden Natten mellem 26. og 27. Juni 1766 ved en ulykkelig Ildebrand blev lagt i Aske, kunde den opbygges større, om Gud dertil vil igen give Evne. (Derefter følger en omstændelig Skildring af Branden og hvorledes Præsten, Hans Christensen Højer, og hans Børn frelstes). Hans Christensen Højer . . . hans Fader var Christen Bossen, Digefoged over Højer Birk og Herred, som døde 1693, Moderen Anna Catharina Hansd., som forblev i hendes Enkestand. Hun lod ham tilholde i Skolen indtil 1702, da hun rejste med ham til hendes Broder Andreas Hansen Højer, som boede paa Ostergaard $i$ Salling*) til at undervises i Husholdningen; 17() faldt hans Morbroders Præceptor Hans Hjersing, sum siden var Præst til Schiveholm i Aarhus Stift og er forst død sidste Aar**), paa at lade ham studere, da han og forblev under privat Information til 1708, da han kom i 5. Lektien i Viborg og 1709 udi Mesterlektien under Mag. Niels Schive og Mag. Jens Ostenfeld, hvorfra han blev dimitteret til Kbhvn., men som

*) Andr. Hansen Høyer, d. 1727, havde 1694 kobt Østergaard i Aasted Sogn.

**) Hans Hjersing blev 1711 Præst i Skivholme. 
Pesten da begyndte at grassere i Kbhvn., maatte han straks efter overstanden Ex. rejse derfra; 1712 rejste han igen til Kbhvn. for at tage Ex. phil. og rejste derfra med en af sine Fættere, som vilde bese sine Fædres Fødeegn Højer og der besøge gode Venner; 1713 rejste de begge med hinanden til Kbhvn. for at sustinere Ex. theol., 1715 i Febr. tog han sin Attestats ..., og som han var sindet at forlade Bogen igen, opholdt han sig mestendels hos sin Morbroder Andr. Hansen Højer paa Østergaard og undertiden hos sin Sroger Peter Petersen i Højer. Han har aldrig sogt om et Præstekald, dog har hans Slægt og Venner givet sig denne Umage derfor. 1725 var han med paa Valg paa det da vacante Præstekald Jerupsled (Hjerpsted), og 1727 ogsaa paa Valg i Rinchenes, hvorover der blev tilskrevet fra en Kobmand $i$ Flensborg, at hvis han vilde protestere mod Valget, vilde de fleste af Menigheden udfore Processen paa egen Bekostning, saasom det var ikke rigtig gaaet til dermed. 1729 blev han kaldet til Fohle . . . Han kom 1730 udi Fgteskab med Apoteker, Raadmand Neumanns Datter i Ribe . . havde i dette Agteskab 3 Sonner og 3 Dotre, hvoraf de to ældste, som var Sønner, dode i deres Barndom; den xldste af de efterlevende er en Datter Christine, g. m. Hr. Radoor i Reisbye, den anden er en Søn, som er Student og har sustineret sine Exam., den 3. er en Datter, g. m. Degnen i Gram Studiosus Morten Clausen, den 4. er ogsaa en Datter, som er forlovet med

Christen Pedersen ... Efter at han hjemme havde lagt nogen Begyndelse til Studeringerne, kom han 
1742 til Sommersted, hvor han nød dav. Præst Wøldikes Information til 1748, da han blev dimitteret, fik 1750 Attestats, rejste i Sept. til Wittenberg, hvor han var $i$ to Aar, og saa $i$ Gøttingen et Aar. Da han kom hjem, underviste han $i$ to Aar Kancelliraad Lautrups Son paa Estrup*), men siden maatte han efter sin Faders Begæring drage hjem igen for at gaa ham til Haande**), indtil han 1766 blev kaldet til sin Morbroders Højers Adjunctus. Vedlagt er en Levnedsbeskrivelse over Højer, vistnok skrevet af Eftermanden og Svigersønnen, Chr. Pedersen, idet Højer var dod 3. Novbr. 1767; men den indeholder intet nyt ud over, at Højer var bleven begravet $\mathbf{i}$ Kirken lige neden for Prædikestolen.

$\mathrm{K}$ i r k e n er en stor og anselig Kirke til en liden Menighed, da Sognet bestaar alene præter-propter af 115 Tdr. Hrtk. Den har et højt Taarn og i samme. en god Klokke og er tækket overalt med Bly, og den lave Kirke er rundt omkring opbygt af de saakaldte hugne Sten og den nederste Rand med en Rad mindre omkring. Den er paa nærv. Tid i en meget god Stand, siden jeg efter sl. Fru Anna Sophie Rantzau, f. Schack, hendes Begæering i Aaret 1758 har ladet den reparere. Der er et Epitafium inden paa den søndre Side af Muren, saaledes lydende, opsat: „Her neden ved Stolen hviler i Gud sl. hensovet hæderbaarne Gud- og Dyd-elskende Demoiselle Ingeborg Gregersd. Fogh, som var født i Pugaard udi Ribe Ao. 167327. Juni. Hendes Forældre var den højlærde Mand

*) Det er Kancellird. Fr. Lautrup til Estrup i Malt Hrd.

**) Faderen var Kobmand P. Auw i Hojer. 
Mag. Gregers Fogh, Rector schol., og den ædle Matrone Karen Pedersd. Kragelund, som levede et ærbart og skikkeligt Liv udi 23 Aar 6 Maaneder, døde her i Fohle Præstegaard 1767 1. Jan.» Af hendes Gave er Kirken med Maling saaledes beprydet.

P'aa Kirkegaarden Sønden Kirken lige for Prædikestolen ligger begraven Ober-Inspector Christian Lehmann ved Schackenborg under en stor Sten. Af den lange Gravskrift: Han var f. 2. Decbr. 1693 i Hobro; Faderen var Sognepræst Jacob Frisenborg; han dimitteredes fra Viborg Skole 1713, tog Attestats 1716, var 10 Aar som Fuldmægtig hos Krigs-General-Fiskal Truels Smit, derpaa 5 Aar hos Stiftamtmand Chr. Carl v. Gabel, hvorfra han kom til Schackenborg, livor han døde 5. Decbr. 1748.
"Men Schackenborg. og Gram vel maa
Med største Længsel sige,
Hvor skal vort Gods og Herskab faa
Den brave Lehmanns Lige?k

Der er kun to Byer i Fohle Sogn, den ene Fohle Dy, hvoraf den ene Del, Kirken nærmest liggende, egentlig kaldes Fohle, den mellemste Del kaldes $\mathrm{Mel}$ lerup, og den længst Kirken fraliggende kaldes Ganderup. Den anden By, som ligger halve Vejen mellem Fohle og Ribe, kaldes Obbekicer, ${ }^{*}$ ) hvilket Navn har sin Oprindelse deraf, fordi den ligger over for en eneste Gaard Abbiskicer, som saa er kaldet, fordi den er bygt udi en Mose af en Abbed.

*) Som bekendt blev Obbekjer ved Freden 1864 skilt fra Fol Sogn og lagt til Danmark som et. eget Sogn. 


\section{Kalslund Herred.}

Lintrup-Hjerting Sogne. Indberetningen, skrevet. af Mikkel Boysen, er dat. 3. Decbr. 1765.

Til Præstelisten: Jacob Sorensen (1664 til 1678) ... f. i Lintrup af Bondestand, hvis Slægtninge endnu er her. - Christen Lauritsen Wellejus . . for sin gravitatiske, ædruelige Opførsel, Belevenhed og store Veltalenhed erhverved han sig Yndest og Anseelse baade hos høje og lave . . og er det bekendt, han ofte paa Kolding Slot prædikede for Kong Frederik, hos hvilken han stod i stor Naade, men endnu udi større hos Enkedronningen Charlotte Amalie, som meget arbejdede paa at faa ham forflyttet til Kbhvns. Slot, da hun egang ${ }^{1}$ is Aar havde ham hos sig og uagtet deres Religions Ulighed hørte ham . . . Han, der af foregaaende Omstændigheder kunde agtes lykkelig, var $\mathbf{i}$ andre Maader ulykkelig, idet han 1681 ved Ildebrand mistede den ganske Præstegaard og 1718 Salshuset.

Hvis Navne Lintrup og Hjerting Kirker har, er ubekendt*). . . Blandt Ornamenterne kan udi Lintrup Kirke regnes en smuk Altertavle, der var beskikket til et adeligt Epitafium og blev overført fra Sjælland 1692, da Kirken 1690 i Juli havde været hjemsøgt af Ildebrand... Norden Alteret en Tavle over Andreas Lintrup og Hustru med deres malede Billeder, og Inskriptionen derpaa, saavidt man kan

*) Lintrup Kirke var indriet til Magdalena; Haupt p. 408. Se ogsaa Sonderj. Aarb. 1906 p. 136 om den ovennævnte Altertavle. 
læse ... Af denne ses, at Tavlen er opsat 1654, og at Hustruen dode 1659. Norden i Koret Tavle over Christen Wellejus og Hustru; af den ses, at han var f. 17. Juni 1657 (ikke 12. Juli, som Wiberg har), og at hun døde 12. Aug. 1738 (ikke 1. Aug., som hos Wiberg). Sønden i Koret udi Ovalform Inskription paa en Tavle, opsat over Christen Wellejus' Søn Laurits Wellejus, Præst til Føvling-Holsted i Ribe Amt, d. 1706 i sine Forældres Hus i Lintrup, og over hans yngste Broder Christian Bernt, d. 31. Decbr. 1696, 8 Aar gl. Neden for staar:

Hvil her nu, kære Søn, som var os her saa lydig Og indtil Enden i dit ganske Forhold dydig.

Du varst $i$ vores Hus saa from og fojelig, Du er i Himmel-Hus som Præst evindelig. Ak, vi vel havde tænkt, du efter os skuld' levet, Vort Hus til Trost, men ak, vi efter dig er blevet. Lev du nu hos din Gud, du døer ej af rort Sind, Før Gud tar os til sig, til dig i Himlen ind.

Sidst kom du, liden Søn, Forst fik du Himlens Lon. Naar Gud vil, faa vi dig At se i Himmerig.

1714.

Her anslaas Kirkernes Tiende ej efter Hrtk. Deres I'dgifter er foruden Reparationer, naar den behoves, for Lintrup Kirke 50 Mk. 4 Sk., Hjerting Kirke som et ringere Sogn nuarkeligt mindre.

Præsteg a rdenes Hrtk. kan, som af foranstaaende ses at være for ubrugeligt, ej specificeres, dog tjener saa meget derom til Efterretning, at Ho- 
vedsognets regnes for en hel Gaard .. Anneksgaarden er derimod saare ringe.

Præstens Navneafledning er morsom; han gaar ikke af Vejen for et eneste Navn. Her anføres: Lintrup Sogn bestaar af 5 smaa Byer foruden Eenbollingerne (!), nemlig Lintrup, der maa have sit Navn af Lindetræer, hvoraf findes endnu et gammelt i min Have, og efter Tradition skal i samme Vesterby være fundet to deslige, under hvilke 7 Læs Hø med to Dages Regnvejr stod ubeskadigede. Mejlby . . . synes at bære Navn af en Møj- eller Hølee, og har den By en Kornmark blandt alle i Sognet. Tornum bærer vel Navnet af Torne [0: Taarne]; hvoraf findes en Del ej langt derfra. Vimtrup, hvis Derivation kan ej udgrundes, undtagen det maaske kunde udredes af »vimse«, da der findes en Del Moser, hvor den saakaldte Lygtemand mærkes at vimse om Sommernætter. Dover, hvis Navn efter en Tradition skal hidledes deraf, at en Rytter for utænkelige Aar siden, da han i Nærværelsen var indkvarteret, hver Morgen skal af samme Mark have hentet en Kærv til sin Hests Davre, naar Kornet stod høstet. Af Enebollingerne findes hos Dover By Foldingbro, der er en Gaard og ligger straks Sønden for Kongeaaen, hvilken maaske kan have Navn af at folde, fordi den store Bro, som findes derhos, ligesom sammenfolder eller føjer Jylland og Slesvig. Aarlund, hvor der maaske fordum har været en Lund ej langt fra Kongeaaen . . . Katkicer, et Hus, som mulig maa have Navnet af et Kiær, som findes derhos, hvor saadant kort Græs, som kaldes Kat-Skjeg, vokser. Norre-Aaling, en Gaard, som 
maaske kan udledes af en Eng ved Nørreaa, hvor man fordum har fanget Aal. Kastbjerg, hvis Bemærkelse kan udledes af Bjærge, som ligger Norden derfor, hvorhos det maa være kastet eller opbygget fra $\mathrm{Be}$ gyndelsen. Kastbjerg-Led, en Gaard, som vel har Navnet af et Led eller Indgang fra den sidst omtalte Mark til den anden. Tornumgaard, en Pensionærgaard, der svarer en aarlig Hyre til Kongen ... Scherreboek Molle, der mulig kan efter Navnet komme deraf, fordi der noget fra hverandre ligger to Møllehuse og en Dam, der maaske i fordums Tid kan have været en stor Bæk, ligger mellem Møllerne, der ved Maalingen ligesom skærer.

De fattige Lernmer plejes af Kirkeblokkene, og naar det, som deri findes, ej forslaar, skyder Sognet sammen til deres Underholdning .. Inspektionen over Fattigvæsenet ledes af Sognepræsten og Rettens Betjentere i Herredet efter en kgl. Forordning.

Af Herregaarde findes ingen, men dog siges Aarlund og N.-Aaling fordum at have været beboede af Adelige, der dog og maa have haft noget dertil liggende Jordegods.

En Høj paa Vimtrup Mark kaldes Proestehoj, maaske fordi Præsten, naar han drager til Annekset, kommer saa nær forbi. Af andre Høje er vel en Del i Lintrup Sogn, der dog ej findes mærkværdige, men uden Tvivl maa have tjent $\mathbf{i}$ fordums Tid til de Dødes Begravelse.

Af Antikviteter findes $\mathrm{i}$ øvrigt intet undtagen dette, at der i Dover By var en Kirke, af hvis Kirkegaards Dige endnu ses nogle Rudera, som jeg selv har 
taget i Øjesyn, menes samme blev afbrændt af de kejserlige, da de under Wallensteins Anførsel i det forrige seculo gjorde Invasion, og skal efter en ikke urimelig Tradition Ulykken deraf have rejst sig, at en Karl, som ved Armeens. Durchmarsch havde lagt sig paa Kirkeloftet med en Bøsse, skød en Hest, som var for en fjendtlig Karm, hvilket Kirken maatte undgælde, der i den senere Tid ej opbyggedes.

Kornavling er Sognefolkets første $\mathrm{N} æ \mathrm{r}$ ing og Fæets Opdræt, hvilket dog her langsomt opdrages for den skarpe Egns Skyld og bliver liden af Vækst. Af Kornsæden er Rug og Boghvede den største.

Hjerting Sogn bestaar af den eneste By Hjerling, der synes at have Navnet af Herre-Ting, muligt fordi der $\mathbf{i}$ ældgamle Tider kan have været en Forsamling af Herrer til at holde Ting eller Retter. Den saavel som derhos liggende og til Sognet hørende Eenbolling Gastrup, bestaaende af een Gaard, der maa hidlede Navnets Bemærkelse af en Gaase-Torp, fordi derved findes nogle Enge, som muligt $i$ ældgamle Tider kunde have tjent til at græsse Gæes paa.

5. N.-Rangstrup Herred.

Toftlund Sogn. Indberetningen, af Ove Thorning, er dat. 22. Febr. 1766; en senere Indberetning er udateret.

Præstens Indledning er saa lydende: Det er vanskeligt og til Dels umuligt at kunne oplyse den af Elde fordunklede Alderdom, der selv har enten forsømt at oplyse sig selv, eller og ulykkelige Tilfælde har borttaget deres Oplysninger, da tillige den itzige og sildere Alder har været ligesom forsømmelig i at 
bekymre sig om det forbigangne, der næppe ved noget om det herværende: Da jeg derfor vilde og skulde $\mathrm{i}$ dybeste Respekt efterleve Ds. Højærværdigheds smukke og i sin Tid nyttige Forlangende, da befandt jeg mig i saa stor pauvrité (!) for alle Hjælpemidler, at jeg fast despererede noget, som kunde være tjenligt at kunne komme fra mig, hvilket især bekymrede mig. Dog efter megen Møje og alt givet Flid, eftersom og forhen i den korte Tid, jeg her havde været, jeg havde om det og dets Antikviteter angaaende, ved alle forefaldne Lejligheder flittig udspurgt og bevaret, har jeg samlet efterfølgende, der dog ikke fyldestgør Deres grundige Rekvisition, men er dog alt det, der kan faas at vide, hvorfor jeg beder allerydmygst, at det gunstigt optages*).

Af Præstelisten: Præsterne til Herrested eller Toftlund Kirke vides ikke nogen sikker Efterretning om forend 1600 (omendskønt der siges, at der var en, som hedte Hr. Peder, og en Hr. Mikkel, var her Præster, men intet mere vides, ikke engang deres Grave eller andet, som læengst staar ved Magt), thi ved det at Herrested By og tillige Præstegaarden afbrændte, saa opbrændte og ventelig alle gamle Dokumenter, Breve, Kirkebøger, Tiendebsger og andre, hvoraf nogen Underretning kunde ses, thi deres Kirkebog er ej ældre end fra 1610. Altsaa er Mads Jacobsen den første og ældste, som der tilvisse kan skrives om. Han ligger begravet i Alteret ( $\curvearrowright$ : Koret) med en Træramme paa sig . . . Marcus Stur . . ligger

*) Han skulde da mindst ligesaa godt som Amrumpræsten (se Senderjydske Aarbøger 1910 p. 17:3) berle om Cndskyldning for sit danske Sprog. 
begravet neden for hans Formand. Anders Clausen med Tilnavnet Schlange (Slange). Paa nør Side i Kirken ved Døbe-Funten ved Alteret er indmuret en langagtig Kvadersten af samme Art, som nu er her brugelig til Ligstene, sort af Farve, hvorpaa $\mathrm{Hr}$. Anders staar udhuggen af Lignelse og Gestalts-Højde i præstelige Klæder; Læsningen er sat med. forgyldte Bogstaver . . Nedenunder ved højre Side af den sI. Mand staar hans forste Hustru i ganske liden Statur udhuggen ... paa venstre Side ligeledes nedenunder ved ham i samme liden Statur staar den 2. Hustru udhuggen, Margreta Jonasdatter Mecklenburg*). Claus Andersen Schlange ... gik i en Del Aar og forrettede Embede tillige med Faderen og nød imidlertid de halve Indkomster af Kaldet . . hans Hustru Elisabeth Schlange døde 1740**). - Christian Outzen havde af 1. Egtesskab Sonnen Ditlev***); 2. Gang var han gift med Else Elisabeth Klinckert, som endnu er efterlevende, og med hvem han avlede tre Børn, hvoraf det første døde, de to endnu levende Sønner er Johan Outzen og Hans Ghristian Outzen; Christian Outzen selv dode 24. Juli $1758^{* * *}$ ). - Ove Thorning fortæller om sin Farfaders Fader, der var Præst i Thorning, at hans Fader var Bonde, og fordi hans Fader slog ham, han ej vel kunde køre Ploven, blev

*) Ifl. Wiberg var han 2.Gang g. m.MargretheJonasd.Snell.

**) Ifl. Wiberg hed hun Elisabeth Marcusd. Stur.

***) Han døde som Præst i Branderup 1789. Ved Indberetningen ligger en af ham forfattet udførlig "Lerneds-Récit" over Faderen, hrori der dog, saa vidt jeg kan se, ikke er noget nyt.

****) Ifl. Wiberg var han 3 . Gang g. m. sin anden Kones Søster Charlotte Amalie, medens Thorning altsaa mener, at den anden Kone endnu levede som Enke. 
Sønnen saa irriteret, at han slængte baade Tømme og Svøbe, løb fra Faderen og gav sig i Skole . . Ove Thorning blev $1751 \mathrm{~g}$. m. Christiane Junghans, Datter af Hans Ghr. J., forhen Præst paa Mandøe, en Søn af Regimentskvartermester Junghans paa Fyn, som nedstammede fra Generaltoldinspektør J. i Ribe Stift, som under Christian I kom ind i Danmark fra Sachsen.

K i r k e n har intet særdeles Navn, vides ej heller, hvad Tid den er bygt; men at det har været i Christendommens Begyndelse, holder jeg sluttelig, fordi den er lang og smalagtig (!). Det almindelige Navn, som Kirken kaldes, er enten Herrested eller Toftlund, det første er det ældste, men er gaaet mere af Brug, dog kaldes den endnu tit og ofte Herrested; saaledes staar der paa Kirkebogen ${ } \mathrm{H}$. Kirkebog gesom de forrige Præsters Kaldsbreve lyder alle paa H. Menighed undtagen Hr. Gutfelds af 1758*) og mit af 1760); saa skrives der tit fra Amtstuen i Haderslev Herrested ... Og er det venteligt, at det er af Byen Herrested, som laa S. og Ø. for Kirken, hvor der vises endnu en Kilde, som har hørt Præstegaarden til, og Marker, hvor Byen har staaet, kaldes HerrestedTofte. Men denne By er ikke mere nu til, men Indbyggerne bor nu i Toftlund By, hvor der, saalænge Herrested var i Stand, ikke boede andre end nogle Toftemænd ... Og siges der, at denne Forflyttelse skete saaledes, at ved frivillig Overenskomst skal et Parti af samme have draget højere ind $i$ Landet, af hvilken en Rytter, som var bleven bag efter de andre,

*) Peder Gutfeld var Prest her 1750 - 
kom ved Aftenstid og spurgte Vej efter de andre, hvorpaa, da en af Indb. i Herrested viste ham der og der hen, som var hen i Moserne, Rytteren, som red denne Vej, mærkede straks, at det var urigtigt, straks vendte sin Hest og red til Byen igen og for at revengere sig skød med skarpe og antændende Ting Byen i Brand, hvorpaa de arme Indb. tog Flugten og retirerede sig til Lunden i Toftlund, hvor de først skjulte sig og dernæst byggede deres Gaarde . . Og altsaa var Herresteds Ødelæggelse Toftlunds Opkomst . . Men hvad Aar denne Fatalitet er sket, ved ingen ikke heller kan sige mig nogen Gerning eller Anledning til samme at kunne faa at vide . . . Thi tænkte jeg først, at det var sket enten 1659 eller 1629, og stod det sidste mig bedst an. Men da jeg erfarede, at Mads' Jacobsen døde $1615^{*}$ ), synes det, at det skulde være sket før, og før den Tid ved jeg ikke, der skete nogen fjendtlig Oversvømmelse under de Oldenborgske Konger uden en liden Ruptur under Kong Hans, om jeg mindes ret ... Altsaa skulde man højere opstige i Alder, enten til Christopher eller Waldemars Tider eller nærmere mod Christendommens Begyndelse, som falder mig urimeligt. Man maa vel forbigaa alt dette og sætte, at Mads Jacobsen kan have boet og døet $i$ de smaa Toftehuse, som da var i Toftlund, for des nærmere at fornøje sig $\mathrm{i}$ den liden Lund. Eller at hans Svigersøn Hr. Marcus Stur kan først efter 1629 eller 30 , som vi vil sætte til det fatale Aar, have ladet gøre

*) Paa den ovenfor omtalte Træligramme stod: Her ligger begravet adle og velagte Mand Mads Jacobsen „i 'Toftlund". 
hans Ligramme, og da, fordi han boede i Toftlund, har ladet sætte $» H r$. M. J. i Toftlund火. Og kommer det mig saameget rimeligere for, som jeg har hørt, at Marcus' Svigersøn Hr. Anders, som kom hertil 1644, er med de første, der byggede (jeg kan forstaa) vel byggede $\mathrm{i}$ Toftlund og satte de forrige Bygninger $\mathrm{i}$. bedre Stand.

Kirken ligger ellers langt fra alle Byer, som der henhører, ud paa Toftlund Mark nær op til det saakaldte Herrested-Tofte, saa at den har lagt Herrested nær, ja saa nær, at Præstegaarden siges at have lağt straks Østen for Kirkediget, hvilket særdeles var bekvemt og er en stor Raritet, hvor det findes. Den er ellers af skikkelig Bygning og muret af nette KvaderKampesten, overalt med Bly bedækket. Taarnet er alene muret af Teglsten og er ikkun af middelmaadig Højde. Men i gamle Dage har det været et temmelig højt og spidst Taarn, som siges at kunne ses baade $\mathbf{i}$ Oster- og Vesterhavet; men 11. Oktober 1634, som er mærkværdig af den her i Landet store og skadelige Storm, blev Taarnespidsen bøjet, saa at de maatte nødes til, siden Kirken ingen Midler havde, at nedbrække det, hvorved Taarnet tabte sin Højelse; bygt med Sparrer, bedækt med Bly. Ø. for Alteret ( ret) er bygget, som det synes sammen med Kirken, en liden Trin Karnap, hvorved man gaar omkring Alteret. Paa den søndre Side af Koret er indbygt et lidet Sakristi af sl. Hr. Outzen som Kirkeværge, men som den egentlige Hensigt ej kunde obtineres, er det ej i Brug, endskønt det staar endnu (Kakkelovnen herudi har Hr. Outzen i Brandrup taget til sig og bru- 
ger den siden 1762, om jeg mindes ret, endskønt Toftlund Kirke ejer den) . . . Kirken har Loft, men for faa Aaringer siden er ny bekostet af $\mathrm{Hr}$. Outzen og ligger under Bjælkerne, saa det gamle endnu ligger ovenpaa.

Norden Alteret udi Hjørnet ved Pillen ses endnu et Maria Billede, noget beskadiget. Altertavlen er ikke af stor Anseelse, dog udstafferet i Billedhuggerarbejde med den Lignelse, at Jesus aad Lammet med sine Disciple. I nordre Side af Alteret et lidet Skab med en Jerndør for som en Rist, indmuret i Muren, hvori der menes, Munkene har haft Kalk og Disk staaende eller Relikvier liggende ligesom særdeles hellige Relikvier $i$ et endnu $i$ samme Skab indhugget dybere Hul. Blandt Kirkens Ornamenter maa tillige regnes Prædikestolen, der virkelig er køn efter Landsbykirkers Maner. Øverst paa Himlen staar: »1654 Fr. 3«. Stolen er ligesom Himlen udført i 6 Afdelinger og Hjørner, og paa hver Afdeling er udført Billedhuggerarbejde meget smukt: Undfangelsen, Daaben, Lidelsen, Opstandelsen, Himmelfarten. Inde paa Himlen under Stolen staar: Denne Prædikestol opsat $1654 \mathrm{og}$ paa Christian Outzens Bekostning malet 1726. Pulpitudet (!), som er bygt over Kirkens vestre Ende, er grøn malet, hvorpaa staar malet 10 Jomfruer, som bærer hver en Lampe, hvoraf de 5 brænder . . . Paa en Kvindestol lige for Kirkedøren staar: Marcus Stuer 1637.

Vores Altertøj er saare ringe og fattigt, thi Kalk og Disk er bar af Tind (!), og er det meget forunderligt, at Kirken har været saa saare fattig, at den ikke kunde forskaffe sig det af Sølv, som dog de allerfleste 
Kirker, hvoriblandt jeg regner Mandøe Kirke*), har, og kan dog ikke koste saameget. Thi vilde jeg derfor allerydmygst bede Ds. Højærv., at De vilde have den Godhed for Kirken at efterse dens Kasse, om det ikke var muligt, at den dermed ogsaa kunde blive prydet ligesaa vel som de andre nære Naboer til saa hellig en Forretnings Ziir.

I Taarnet findes en Klokke, hvorpaa staar med store latinske Bogstaver: "Salvator Mundi Deus Salva Nos. M. Andreas Petri Romdorpius præpositus Rip. H. Marcus Stur Sognepræst 1642.« Dernæst er at se paa Klokken et Maria Billede med Barnet paa Armen og rundt om tre Brystbilleder af Mandspersoner. Nedenunder staar et Vaaben eller Sign., hvilket skal betyde Klokkestaberens Navn(laus Wiolo**). Hvorom findes opskrevet $i$ en gammel Bog af bemeldte Præst, at Klokken blev støbt 2. Decbr. 1642 i Vaabenhuset ved Kirken udi 4 Timers Tid.

Uden Kirken findes mærkværdigt: At ved enhver Side af den søndre Kirkedør er en trind Pille af

*) Thorning havde været Præst paa Manø 1750-60).

*) Hvem var denne Claus Wiolo: Ifl. F. Uldall, Danm. Kirkeklokker (p. 68) er en af Mariager Kirkes Klokker støbt 1639 ,af Franskmanden Francois Voillard og C-V (maaske en Broder)", og i Registret over Klokkestobderne staar om dem: „Stobere fra Frankrig, der har arbejdet i Danmark ('a. 1638-42". Thorning afhilder stubereus Mærke som et Vaabenskjold. ovenover hvilket staar et $\mathrm{M}$ og paa hver Side et $\mathrm{C}$ og et $\mathrm{V}$, og inde i Skjoldet har han skrevet: "Heri en liden Klokke“. Manden har vel san heddet Claude Voillard. For øvrigt nævner Haupt blandt Klokkestaberne (III p. 41) en Steffen Wolle eller Voillo, der ved 1645 kom til Hertugdommerne. Danske $\Lambda$ tlas (VII p. 182), og efter det Haupt (I p. 416), siger, at Klokken var stabt 1646 (den er der ikke mere). Præstens Aarstal er utvivlsomt det rigtige. 
Kamp, 21/8 Al. høj, ganske slæt, men med en firkantet Afslutning foroven. Den nordre Kirkedør er tilmuret med Teglsten, men paa begge Sider findes ligeledes en Pille, hvor paa den vesterste paa dens øverste Afslutning findes en Løve udhuggen, men paa den østerste et Blomster, uden Tvivl et Neldeblad [Lilie]. Paa den anden Pille paa nør og vester er udhuggen (et Vaaben), hvilket jeg ikke ved skal være.

Paa K irkega a rden er to store Høje, V. for Taarnet, hvoraf den sendre er høj og meget spids, men den nørre er flad og slet ovenpaa. De er og ikke nær saa høje som Jellinge Høje, som jeg har set*) ... . Saavidt jeg ved, ved den vestre Port paa Kirkediger er bygt et lidet Hus paa tre Fag, som bruges til at staa i Ly udi for Regn og Slud, som Kirken holder vedlige. Af de 12 Ligsten paa Kirkegaarden, som Præsten nævner, er formentlig kun flg., der laa lige uden for Kirkedøren, af Interesse: Her under hviler sl. Jørgen Lauridsen Oxholm, f. 1654 i Oxbøll Sogn paa Alse, kaldet til Sognedegn i Herrested Sogn 1685, kom i Egteskab med Anna Hansd. af Rurup 1693, døde 1729, 75 Aar; hans Hustru døde 1717, 51 Aar. Derpaa folger et Vers, og under dette staar: Hafniæ 1743 L. 0. H. Disse Bogstaver betyder Lorentz Oxholm, som er Krigsraad og Mønsterskriver ved Holmen som er endnu levende og i Tjeneste. Han var de afdødes yngste Søn og var født her i Toftlund, hvor hans ældre

*) Se Sønderj. $\Lambda$ arb. 1895 p. 184 Fortællingen om den polske Officer, der 1659 mishandlede Præsten Anders Clausen og mange $\Lambda$ ar efter, da han var kommen for at bede om hans Tilgivelse, døde ved Toftlund Kirke og blev begravet $i$ en af Kæmpehøjene ved Kirken. 
Broder var Degn; han kom til København som Skræderdreng, som var hans Profession; siden blev han, fordi han var meget høj og velskabt, Hejduk hos sl. Kong Christian VI, derfra avancerede han til Mønsterskriver og Krigsraad, og ham er det, der bekostet denne Sten over sine Forældre, thi staar der og paa den "Hafniæ«").

P r s t e ga arden i Toftlund er først opbygt af Hr.Claus**) - thiHr.AndersSlange havde bygt paa en anden Gaard i Byen, hvor han boede og døde er forbedret af $\mathrm{Hr}$. Chr. Outzen, kun af maadelig Bygning, bestaar af 5.3 Fag Hus, saavel Ude- som Indehuse, er takseret $\mathrm{i}$ Grund-Assurancekassen i Haderslev for $483 \mathrm{Rd}$. 82 Sk. tillige med et Lejehus Præstegaarden tilhørende for $36 \mathrm{Rd}$. Bestaar efter den her ude bruyelige Maade at regne af 2 Ottinger eller en halv Gaard, har ellers Ager og Eng med de andre halve Gaarde, følgelig intet, som dog de fleste Præstegaarde har, noget særdeles eget. I Stenderup ligger et Stykke firkantct Eng, som Præsten avler med hvert Aar af 4. Læs Hø saa nær som en 16 lart deraf i norder Ende, hvilket saaledes efter Traditionen siges at være sket: at der for og straks efter Reformationen skuldn en af Ribe latinske Skoles Disciple forrette Degneembede i Kirken og derpaa spise skiftevis hos Bouderne i Soguet samme Dag; dette befandt de fleste sig ikke vel ved, og derfor med Øvrigheden i Haderslevs Consens gav hver halve Gaard i Stenderup et

*) Lorentz Oxholm var født 1726 og døde 1768 i Novbr Jørgen Laurids Oxholm er sikkert Stamfader til Familien Oxholm.

$\left.{ }_{* *}^{*}\right)$ Se Rhode, Haderslev $\Lambda$ mt p. 484. 
lidet Stk. Eng, som blev samlet paa eet Sted, til Præsten for at spise samme Person, saa nær som en Bonde, som vel muligt havde villet, men ikke maatte for $\sin 6$ vrighed, som den Tid sorterede til Lygomkloster Aint.

Byerne: Toftlund, bestaaende af 10 Ottinger tiI Haderslevhus, 4 til Grevedømmet Schackenborg, 3' store Kodner, hvoraf hver skatter 12 Sk. maanedlig, og 4 smaa; Byen har gode Moser, god Mark, men lidet af Hø, hris Mangel ersættes af Gidstoft (?) og andre Steder. Stenderup har 32 Ottinger, hroraf 30 , horer til Haderslevhus og 2 til Lygumkloster Amt; iblandi dem, sum hører til Haderslevhus Amt, er nogle af de saakaldtes Moustes Tjenere, nemlig Mourids Pudiluskes Tjenere, som siges at have anslaget en Del at sit Gods for hojt og skiftet det bort mod kongeligt, hrilket af Bønderne var meget ilde anset, indtiI de af hgl. Naade blev nedsatte . . . Allerup bestaar af 16 Ottinger, alle til Haderslevhus Amt; den er bygt nettest i Sognet og ligger i en lige Linie med sine inddelte Tofter S. for sig og Marken straks N. for sig og gaiır lige op ti' IIusene. Ørderup bestaar af $16 \mathrm{Ot}-$ tinger, alle til Haderslevhus; Byen har to halve Gaarde, saakaldet Lychegaard, som den har kobt og fordelt melleru sig. men tiender af samme til Thislund... Romet bestaar af 8 Ottinger, som henhører til Lygumkloster Ant ... S. og $\emptyset$. for Toftlund ligger en halv Gaard Kicergaard, henhører til Haderslevhus Amt. S. for Toftlund ved Haver Bæk ligger Mucrspang, et dobbelt Kod. Der kunde meget mageligt anlægges en Vandmølle til stor Lettelse for Sog- 
net, som ellers skal køre til Thestoft Mølle, en stor Nil at kore og til Dels Stenvej. - Disse 88 Ottinger er afdelte i 49 Decimanter.

Personernes Antal over 12 Aar er ungefehr af og til 430. Der er 392 Communicanter, men dette konsidelable Tal paa saa faa Decimanter udgør Knippelpigel'. som her opholder sig $\mathrm{i}$ de smaa Byer.

Om Herresteds Navns Oprindelse maa jeg ikke forglciume at meddele: a) at da Kirken begyndte at bygges paa, paa et andet Sted, nemlig i Toftlund $\mathrm{By}$, paa dri Sted, hvor nu kgl. Toldbræt udhænger (hvor Toli redlægges til Forpagterne i Toftlund med en siare liden Tribut, nemlig $1-2,3$ Sk. af Lossegodset, (:), Købmandsvarer og andet som Potter, Fisk, Træe etc. fra Aabenraa til Ribe, som er den alfare Vej, og ${ }^{1} 2$ Sk. af hver Stk. Stud af Nor Jylland til Holland eiler Hamborg), hvilken Plads til Kirken ikke kunde have veret lagt bekvemmere, da den er saa godt som Cientrum i Sognet, siges der, at Materialerne blev forflyttede fra det Sted til det Sted, hvor Kirken nu staar paa, som er et højt Sted paa Toftlund og Herrested Marker, samt tillige berettes, at der hørtes en Rist med disse Ord: IIer er Sted. Men dette anses for ridicul og uviist. Men dette b) synes at være viis og Lirl tillige stor Rimelighed for Situationens Skyld: at Navnet er det samme som Herrernes Sted; thi som H. $\in \mathbf{r}$ som et Centrum i Landet for Købstæderne Ribe, Haderslev, Aabenraa, Tønder, hvortil der er snart lige langt, skal i fordums Tid, som et og andet var at deliberere over i Krigstider og i Fredstider ...., har de deputerede Herrer der forsamledes tillige med 
de omliggende Herremænd, som fra Slottet Arrildskolın, Friesvold, hvoraf Rudera endnu er at se, Abildgilardkiær paa Højerup Mark, Gielstoft i Gram Sogn, Gammelskov i Agerskov Sogn m. fl. . . Og var der ti! den Ende bygt et Tinghus ved Kirken, Herrested Tinghus ...

Der er 8 fat tig e Lemmer i Sognet, hvoraf en faar 12 Sk., to 6 Sk., fire 4 Sk., en 3 Sk. ugentlig, ligesom de er trængende og svage. Til disse Penge skyder hver Otting $1 \mathrm{Sk}$. maanedlig, som Helligdagsfogderne indsamlèr og bringer til Kasseforstanderen, hvor Præsten har Inspektion ... .

Her er kun een Skole i Sognet, i Stenderup By, kont opmuret for en Snes Aar siden, hvortil de lejer og underholder en Skolemester. De andre Byer underholder en Skolemester i deres Huse. Lønnen er $1 \mathrm{Sk}$. hver L'ge af hvert Barn, eller og de er akkorderet med ham om en vis Løn. Overalt mestendels holdes kun Skole om Vinteren undtagen i Toftlund, hror Degnen holder Skole, og hror der og holdes om Sommeren, og de andre Byers Børn kunde gerne søge hertil, dersom Forældrene ellers var at persvadere, men de paastaar, at deres Born bliver forknyttede af den sommerlige Skolegang, hvorfor de ikke uden nogle faa er at overtale.

Paa Stenderup Mark Norden Byen har været et saakaldet berommeligt Helligvand, blev søgt af mange, og derfor paa Vejen til Stenderup blev sat en Arm-Blok 1681, hroraf Pengene blev brugte til Kirken og Sognets Fattige. Den vedvarede til 20. Decbr. 1708, da ingen siden kom til dette Helligvand. 
Af $\mathrm{H} ø \mathrm{j}$ e findes, foruden de to paa Kirkegaarden, to store udenfor, kvis fire Lige skal ikke findes i N.-Rangstrup IIrd. af Høje, og det er og ventelig, at derudi er Begravelser. Norden for Atterup Mark findes et Hedninge-Offersted, som har staaet med tre Sten og en bred derovenpaa liggende og andre straks runden om i Højen.

En Kuriositet er endnu at finde, nemlig Rudera og Tegn til to Glaspusterier i Toftlund, hvor endnu Grøn-Zinner med Slag er at finde. Paa Holteskov Østẹn Toftlund har staaet en mægtig Skov med Dige omkring og Port for, som Svenskerne i den sidste Oversvømmelse ødelagde og solgte til de fyrstelige i Aabenrade Amt.

Sognets bedste $\mathrm{N}$ æ r in g er Pløjen af Jorden og det, som fortjenes med Hænderne. Til den første henhører Rugget, thi Byg og Havre vil ej vel vokse, fordi Grundẹn er for slap. Dernæst er Tadderie eller Boghvede*) den bedste, som falder her fortrinlig. Af disse to Dele sættes mest af. Af de to andre haves ikke til fornøden Brug. Ingen andre Fabriquer findes i Sognet uden Kniplingsfabriquet, som Kvindekønnet gift og ugift øver, og sættes Kvinderne fra tidlig Tid til, naar de er 6-7 Aar gamle, og er der de Piger, som derved kan fortjene $30 \mathrm{Rd}$. vel mere aarlig, naar hun er flittig og forstaar sin Profession til Gavns. Kniplingerne afsættes til Tøndringerne, som rejser omkring i Sognet og har deres Piger, som knipler og skærer af for dem, og andre, som rejser dermed til København og andre Steder og, saavidt

*) Tadder er Boghvede og afledes oftest af Tater (Kalkar). 
man kan forstaa, fortjener brav derved. Og ved jeg ikke, hrad Indb. i disse besværlige Aaringer skulde have deres mangfoldige Udgifter af, dersom de ikke havde haft disse Fabriquer.

I øvrigt ligger Sognet paa en meget skarp og stenet Grund, er derfor meget mager og tør skal have haft megen Arbejde og Træl ... Græsgangene til Kreaturerne er kun slette ... og derfor malker Køerne kun lidet.

Mergelen, her findes nogle Steder, er temmelig god, i Toftlund By er den allerslettest, men i Rømet - og Ørderup den allerbedste, hvorfor de to Byer brænder Teglsten af bedste Art, der er saa gule og duragtige ( 0 : durable) som Flensborg Klinker; naar de sæelges, er Kobet deraf $1 \mathrm{Mk}$. $8 \mathrm{Sk}$. for 100, I de andre Byer bræendes de og, dog ej saa gode. . Og som der overalt i Sognet i hver By er 3, 4, 6 Teglovne, saa er Sognet vel opbygt, og Husene bestaar af lutter Mur. Paa Stenderup Mark og Ejendomme findes en Jord, kaldet Porspletter, en rødbrun Mergel, som er ganske fin, fed og god og bruges til at bestryge Murene med, forend de bliver afpenslede.

Der siges, at Thislund, som nu er Anneks til Beftoft, har lagt i fordums Tid som Anneks til Toftlund, og vises endnu paa Ørderup Enge en Hulvej, hvor Vejen fra Toftlund Kirke til Thislund har gaaet, og bekræftes denne Tradition af det, at Thislund Sogn er meget lig Toftlund Sogn i Afgift til Præsten; saaledes giver de begge ingen Føl-, Kalve- og Lamtiende in rerum natura, som de andre Sogne i N.-Rangstrup Hrd., til sine Præster, men i dets Sted 1 Sk. af hvert Slags, som derfor er saa godt som intet. (Fortsættes.) 